TÉCNICAS DE CRIAÇÃO E BIOECOLOGIA DE Diabrotica speciosa (Germar, 1824) (COLEOPTERA: CHRYSOMELIDAE)

\author{
JOSÉ MARIA MILANEZ
}

Engenheiro Agrônomo

Orientador: PROF. DR. JOSÉ ROBERTO POSTALI PARRA

Tese apresentada à Escola Superior de Agricultura "Luiz de Queiroz", da Universidade de São Paulo, para obtenção do título de Doutor em

Ciências, Área de Concentração: Entomologia.

PIRACICABA

Estado de São Paulo - Brasil

Novembro - 1995 
Dados Internacionais de Catalogação na Publicação (CIP)

DIVISÃO DE BIBLIOTECA E DOCUMENTAÇÃ̃ - Campus "Luiz de Queiroz"/USP

\section{Milanez, José Maria}

Técnicas de criação e bioecologia de Diabrotica speciosa (Germar, 1824) (Coleoptera: Chrysomelidae). Piracicaba, 1995.

102p.

Tese - ESALQ

Bibliografia.

1. Praga agrícola 2. Vaquinha verde-amarela - Bioecologia I. Escola Superior de Agricultura Luiz de Queiroz, Piracicaba

CDD 632.76 
TÉCNICAS DE CRIAÇÃO E BIOECOLOGIA DE Diabrotica speciosa (Germar, 1824) (COLEOPTERA: CHRYSOMELIDAE)

José Maria Milanez

Aprovada em: 13/02/1996

Comissão Julgadora:

Prof. Dr. José Roberto Postali Parra

ESALQ/USP

Prof. Dr. José Djair Vendramin

ESALQ/USP

Prof. Dr. João Roberto Spotti Lopes

ESALQ/USP

Dr. José Roberto Salvadori

EMBRAPA/CNPT

Dr. Andre Luis Lorenção

IAC

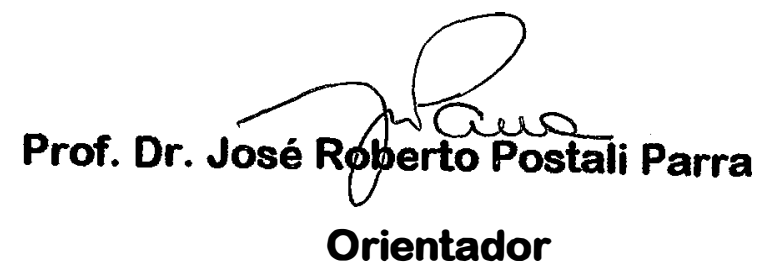


Aos meus pais, Carolina e Luiz;

À minha esposa, Maria Rosa;

Aos meus filhos: André, Andrea e Flavio

DEDICO 


\section{AGRADECIMENTOS}

Ao Dr. José Roberto Parra, Professor Associado do Departamento de Entomologia da ESALQ/USP, Piracicaba, pelá orientação, confiança, amizade e apoio na condução deste trabalho;

Aos professores do Departamento de Entomologia da ESALQ/USP pelos ensinamentos, amizade e apoio recebidos;

Ao Conselho Nacional de Desenvolvimento Cientifico e Tecnológico (CNPq) pela concessão de bolsa de estudo durante o curso;

À Empresa de Pesquisa Agropecuária e Extensão Rural de Santa Catarina S. A. (EPAGRI), pelo apoio e oportunidade de realizar o Curso;

Ao Dr. Sergio Oliveira Moraes, do Departamento de Física e Meteorologia da ESALQ/USP, pela análise física do solo;

Às colegas Laila Herta Mishfeldt e Cleodete Angélica Brunetta, da Fundação Faculdade de Agronomia "Luiz Meneguel" de Bandeirantes-Pr., pela valiosa e inestimável colaboração na coleta dos insetos;

Ao colega Heraldo Negri de Oliveira, funcionário do Departamento de Entomologia da ESALQ/USP, pela amizade e pelo valioso trabalho fotográfico;

Às bibliotecárias Kátia M. P. de Andrade e Eliana M. G. Sabino, pela revisão das referências bibliográficas;

Ao meu filho André Luís Milanez, pela colaboração na área de informática;

Aos colegas Flávio Quental Rodriguez e Gilberto Batista Castor Marques, estudantes do Curso de Agronomia e estágiários do Departamento de Entomologia da ESALQ/USP, pelo auxílio na condução dos trabalhos de campo e de laboratório; 
A Neide Graciano Zério, funcionária do Laboratório de Biologia de Insetos do Departamento de Entomologia da ESALQ/USP, pelo auxílio nos trabalhos de laboratório;

Aos colegas do Curso de Pós-graduação em Entomologia, pelo companherismo e amizade;

A todos os funcionários do Departamento de Entomologia da ESALQ/USP e todas as pessoas que direta ou indiretamente colaboraram na realização deste trabalho. 
SUMÁRIO

PÁGINA

LISTA DE TABELAS. . . . . . . . . . . .

LISTA DE FIGURAS. . . . . . . . . . . .

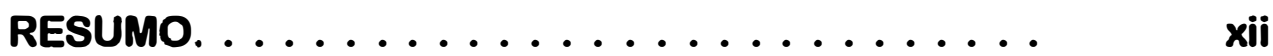

SUMMARY. ................. xv

1. INTRODUÇÃO. . . . . . . . . . . . . 1

2. REVISÃo DE LITERATURA. . . . . . . . . . . . . 3

2.1. Biologia e criação de $D$. speciosa em dieta natural ................... 4

2.1.1. Fase de ovo. ............. 4

2.1.1.1. Coleta, desinfestação superficial e sobrevivência. ........ 4

2.1.1.2. Exigências térmicas e armazenamento de ovos. . . . . . . . 6

2.1.2. Fase larval. . . . . . . . . . . . . $\quad 8$

2.1.3. Fase pupal. . . . . . . . . . . . 11

2.1.4. Fase adulta. . . . . . . . . . . . . . 12

2.2. Biologia e criação de $D$. speciosa em dieta artificial. .................... 14

2.3. Influência de fatores abióticos e bióticos na biologia de crisomelídeos. . . . . . . . . . 15

2.3.1. Influência das propriedades do solo na oviposição. . . . . . . . . . . 15

2.3.2. Influência de plantas hospedeiras na öviposição.

18

2.3.3. Atratividade por cores mono e policromáticas. . . . . . . . . . 20

3. MATERIALE MÉTODOS. . . . . . . . . . . . 22

3.1. Biologia e criação de D. speciosa em dieta 22 natural. . . . . . . . . . . . . . . . . . . . .

3.1.2. Postura e coleta de ovos em laboratório. 24

3.1.3. Fase larval. . . . . . . . . . . . . . 24

3.1.4. Fases de pré-pupa e pupa. . . . . . . . 25

3.1.5. Fase adulta. . . . . . . . . . . . . . 26

3.2. Biologia e criação de $D$. speciosa em dieta artificial. 
PÁGINA

3.2.1. Fase larval. . . . . . . . . . . . . . . . 29

3.2.2. Fases de pré-pupa e pupa. . . . . . . . . $\quad 30$

3.2.3. Fase adulta. . . . . . . . . . . . . . . 31

3.3. Periodicidade de postura de D. speciosa. . . . 31

3.4. Influência do fotoperiodo no período de incubação e na viabilidade de ovos de $D$. speciosa. . . . . . . . . . . . . . 32

3.5. Influência de diferentes cores de gaze na oviposição de D. speciosa. . . . . . . . . . .

3.6. Efeito da temperatura e determinação das exigências térmicas no ciclo biológico de $D$. speciosa. . . . . . . . . . . . . 3.6.1. Fase de ovo. . . . . . . . . . . . . $\quad 33$ 3.6.2. Periodo de larva-adulto. . . . . . . . . . 34

3.7. Influência de fatores abióticos e bióticos na biologia de $D$. speciosa. . . . . . . . . . . . .

3.7.1. Influência do tipo e umidade do solo na oviposição de D. speciosa . . . . . . . . .

3.7.2. Influência de plantas hospedeiras na oviposição de D. speciosa. . . . . . . . .

3.8. Atração de adultos de $D$. speciosa à luzes de diferentes comprimentos de onda. . . . . . .

3.9. Armazenamento de ovos.

3.10. Análises estatística e de sobrevivência de adultos de $D$. speciosa. . . . . . . . . . .

4. RESULTADOS E DISCUSSÃO. . . . . . . . . . . . .
4.1. Biologia de D. speciosa em dietas artificial e natural ................... 43

4.1.1. Duração das fases de larva, pré-pupa e

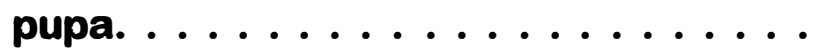

4.1.2. Fase adulta. . . . . . . . . . . . .

4.1.2.1. Período de pré-oviposição e oviposição. . . . . . . . .

4.1.2.2. Fecundidade.

4.1.2.3. Longevidade de adultos ... . .

4.1.2.4. Periodicidade de postura. . . . .

4.1.3. Influência do fotoperíodo no periodo de incubação e na viabilidade de ovos de D. speciosa.

4.2. Influência de diferentes cores de gaze na 
PÁGINA

4.3. Efeito da temperatura e determinação das exigências térmicas no ciclo biológico de $D$. speciosa. . . . . . . . . . . . . . 4.3.1. Fase de ovo. . . . . . . . . . . . . . . 62

4.3.2. Período de larva-adulto. . . . . . . . . . . 64

4.4. Influência de fatores abióticos e bióticos na oviposição de D. speciosa. . . . . . . . . . . 68

4.4.1. Influência do tipo e umidade do solo na oviposição. . . . . . . . . . . . . . . . 68

4.4.2. Influência de plantas hospedeiras na oviposição. . . . . . . . . . . . $\quad 71$

4.5. Atração de $D$. speciosa à luzes de diferentes comprimentos de onda. . . . . . . . . . . .

4.6. Sistema de criação de D. speciosa em laboratório. . . . . . . . . . . . . .

4.7. Armazenamento de ovos de D. speciosa . . .

5. CONCLUSÕES. .................. 82

REFERÊNCIAS BIBLIOGRÁFICAS. . . . . . 85

ANEXOS. ................... 98 


\section{LISTA DE TABELAS}

TABELA №

PÁGINA

01. Dados da curva de retenção de água (bar) em Terra Roxa Estruturada Distrófica. . . . . . . . . . .

02. Duração da fases de larva, pré-pupa e pupa de $D$. speciosa, criada em dietas natural e artificial. Temperatura $25 \pm 2{ }^{\circ} \mathrm{C}$; UR $60 \pm 10 \%$; Fotofase: 14 h. . . . . . . . . . . . . . . . . . . .

03. Largura média e razão de crescimento de cápsulas cefálicas de $D$. speciosa, criada em dietas natural e artificial. . . . . . . . . . . . . .

04. Duração média (dias) dos períodos de préoviposição e oviposição de D. speciosa, criada em dietas natural e artificial, durante a fase larval. . .

05. Número médio de posturas por fêmea, número médio de ovos por fêmea e viabilidade de ovos de D. speciosa, criada em dietas natural e artificial, durante a fase larval . . . . . . . . . . . . . . . .

06. Longevidade média de machos, fêmeas e fêmeas + machos de $D$. speciosa, criada em dietas natural e artificial, durante a fase larval . .

07. Influência do fotoperíodo na incubação e viabilidade de ovos de $D$. speciosa. Temperatura $25 \pm 2{ }^{\circ} \mathrm{C}$; UR $60 \pm 10 \%$. . . . . . . . . . . . . . . .

08 . Número médio de ovos de $D$. speciosa colocados em substratos (gaze) de diferentes cores. Temperatura $25 \pm 2^{\circ} \mathrm{C}$; UR $60 \pm 10 \%$; Fotofase: 14 h. . . . . . . . . . . . . . . . . . . .

09. Período médio de incubação e viabilidade de ovos de $D$. speciosa, sob diferentes temperaturas. UR $60 \pm 10 \%$; Fotofase: $14 \mathrm{~h} . . . . . . . . . .$.

10. Periodo médio de desenvolvimento e viabilidade do periodo larva-adulto de $D$. speciosa em dieta natural, sob diferentes temperaturas UR $60 \pm$ 10\%; Fotofase 14 h. . . . . . . . . . .

11. Temperaturas base (Tb), constantes térmica (K), equações da velocidade desenvolvimento (1/D) e coeficientes de determinação $\left(R^{2}\right)$ das diferentes fases do ciclo biológico de $D$. speciosa, criada em dieta natural. . . . . . . . . . . . . . . 
PÁGINA

12. Número médio de ovos colocados por D. speciosa, em diferentes tipos de solo, em teste de livre escolha. Temperatura $25 \pm 2^{\circ} \mathrm{C}$; UR $60 \pm 10 \%$; Fotofase: 14 h. . . . . . . . . . . . . . . . .

13. Número médio de ovos colocados por $D$. speciosa, em solo com diferentes teores de umidade, em teste de livre escolha. Temperatura $25 \pm 2^{\circ} \mathrm{C}$; UR $60 \pm 10 \%$; Fotofase: $14 \mathrm{~h}$.

14. Número médio de ovos colocados por $D$. speciosa em solos com diferentes plantas hospedeiras e no solo nú (Terra Roxa Estruturada), em teste de livre escolha. Temperatura $25 \pm 2{ }^{\circ} \mathrm{C}$; UR $60 \pm 10 \%$; Fotofase: 14 h. . . . . . . . . . . . . . . . .

15. Número médio de fêmeas, machos e fêmeas + machos de $D$. speciosa atraídos por luzes de diferentes comprimentos de onda. . . . . . . . . .

16. Viabilidade de ovos $D$. speciosa em função do tempo de armazenamento. Temperatura $11^{\circ} \mathrm{C}$; UR 100\%; Escotofase 24 h. . . . . . . . . . . . . 


\section{LISTA DE FIGURAS}

01. Método de criação de $D$. speciosa em laboratório A) bandeja contendo milho germinado; B) peneiramento de larvas de 30 ínstar; C) bandeja com divisória perfurada dando acesso para as larvas puparem no solo. . . . . . . . . . . . . . . .

02. Gaiola para observação da longevidade e fecundidade de $D$. speciosa. a) gaze preta para postura; b) folha do feijoeiro para alimentação: c) tampa transparente da gaiola. . . . . . . . . . . .

03. Tipos de solo estudados: A) Terra Roxa Estruturada Distrófica; B) Latossolo Roxo Distrófico; C) Cambissolo Húmico Álico; D) Terra Roxa Estruturada Latossólica. . . . . . . . . . . . .

04. Aparelho de teste para atração de insetos a luzes de diferentes comprimentos de onda. a) Câmara central para liberação de insetos (BOTELHO et al. 1973) . . . . . . . . . . . . . . . . . .

05. Fases do ciclo biológico de D. speciosa A) ovo; B) larva de 10 instar; C) larva de 30 ínstar; D) prépupa; E) pupa; F) adulto. . . . . . . . . . . . . . . .

06. Larva (A) e adulto (B) de D. speciosa criados em dieta artificial. . . . . . . . . . . . . . . . .

07. Curva de distribuição de frequiência de larguras de cápsula cefálicas de larvas $D$. speciosa criada em dieta natural. As setas indicam os ínstares. . .

08. Curva de distribuição de freqüência de larguras de larvas $D$. speciosa criada em dieta artificial. As setas indicam os ínstares . . . . . . . . . . . . . .

09. Ritmo de postura de $D$. speciosa criada em dieta natural e artificial, durante a fase larval . . . . . . .

10. Sobrevivência de fêmeas, machos e fêmeas + machos de $D$. speciosa, cujas larvas foram criadas em dieta artificial. Valores observados e estimados pela equacão de Weibull em temperatura de $25 \pm 2^{\circ} \mathrm{C}$; UR $60 \pm 10 \%$; Fotofase: 14 h. . . . . . . . . . . . . . . . . 
PÁGINA

11. Sobrevivência de fêmeas, machos e fêmeas + machos de $D$. speciosa, cujas larvas foram criadas em dieta natural. Valores observados e estimados pela equação de Weibull em temperatura de $25 \pm$ $2^{\circ} \mathrm{C}$; UR $60 \pm 10 \%$; Fotofase $14 \mathrm{~h} . \ldots . . . . .$.

58

12. Periodicidade de postura de $D$. speciosa, proveniente de dieta natural, em condições de laboratório. Temperatura $25 \pm 2^{\circ} \mathrm{C}$; UR $60 \pm 10 \%$; Fotofase:14 h. . . . . . . . . . . . . . . . .

13. Relação entre a temperatura com o tempo de desenvolvimento da fase de ovo, período larvaadulto e do ciclo biológico (ovo-adulto) de $D$. speciosa. . . . . . . . . . . . . . . . .

14. Percentagem de machos, fêmeas e machos + fêmeas atraídos por luzes de diferentes comprimentos de onda. . . . . . . . . . . . . . .

15. Sistema de criação de $D$. speciosa em condições de laboratório. . . . . . . . . . . . . . . . . 
TÉCNICAS DE CRIAÇÃO E BIOECOLOGIA DE Diabrotica speciosa (Germar, 1824) (COLEOPTERA : CHRYSOMELIDAE)

Autor: José Maria Milanez Orientador: Prof. Dr. José Roberto Postali Parra

\section{RESUMO}

Foram desenvolvidas técnicas de criação e estudada a bioecologia de Diabrotica speciosa (Germar, 1824) em laboratório, visando fornecer subsídios que contribuam para uma melhor compreensão do comportamento do inseto, e facilitem o seu controle, desde que o seu ciclo biológico é influenciado por diversos fatores bióticos e abióticos, ainda não definidos. A biologia do inseto foi estudada tendo como fonte de alimentação, para as larvas, milho germinado, e para adultos, foliolos de feijoeiro. A dieta artificial à base de germe de trigo e caseína, para as larvas, permitiu o desenvolvimento de D. speciosa, embora tenha alongado o ciclo biológico em relação à dieta natural. Em ambas as dietas, o inseto 
apresentou três ínstares larvais, sendo que as fêmeas criadas em dieta natural foram mais fecundas e menos longevas. Os picos de postura, em dieta natural, ocorreram no 30,70 e $1^{\circ}$ dias de postura, enquanto que em dieta artificial o maior número de ovos foi colocado no 3 60 dias. A postura é realizada, preferencialmente, durante o dia e, a maior atividade de postura, em condições de laboratório, foi observada no período das 14 às 18 horas. $O$ fotoperíodo de 14 horas de luz e 10 de escuro, normalmente utilizado em laboratórios de criação, não afetou o desenvolvimento embrionário e a viabilidade dos ovos. Observou-se, uma relação inversa entre o tempo de desenvolvimento de $D$. speciosa e a elevação de temperatura, na faixa de 18 a $32^{\circ} \mathrm{C}$, nas diferentes fases da vida do inseto. Os limites térmicos inferiores de desenvolvimento (Tb) das fases de ovo, período larva-adulto e do período ovo-adulto foram de $11,1,10,9$ e $11,4^{\circ} \mathrm{C}$, respectivamente. As constantes térmicas (K) para as fases de ovo, período larva-adulto e de ovo-adulto foram de 119,1, 355,9 e 474,9 graus-dia, respectivamente. D. speciosa preferiu ovipositar no solo Terra Roxa Estruturada Distrófica de coloração escura, com umidade variando entre 26 e $63 \%$. O milho foi a planta hospedeira mais atrativa para postura, seguida do feijoeiro e da soja. As fêmeas discriminaram as cores do substrato artificial de oviposição (gaze), colocando maior número de ovos em gaze de coloração preta e verde. As luzes emitidas na região de comprimento de onda ultra violeta (BLB e BL) e a azul (B), foram as mais 
atrativas para machos e fêmeas de $D$. speciosa. A metodologia utilizada para o estudo do ciclo biológico do inseto, foi adequada e proporcionou condições para o desenvolvimento de um sistema de criação em larga escala, em dieta natural. A possibilidade de armazenar os ovos desta espécie no limite térmico inferior de desenvolvimento $\left(11,1^{\circ} \mathrm{C}\right)$, pelo período de 56 dias, poderá também contribuir para a manutenção contínua da criação em laboratório. 
REARING TECHNIQUES AND BIOECOLOGY OF Diabrotica speciosa (Germar, 1824) (COLEOPTERA: CHRYSOMELIDAE) UNDER LABORATORY CONDITIONS

Author: JOSÉ MARIA MILANEZ

Adviser: Prof. Dr. JOSÉ ROBERTO POSTALI PARRA

\section{SUMMARY}

Rearing techniques of Diabrotica speciosa (Germar, 1824) were developed to study the bioecology of this pest under laboratory conditions, knowing that the understanding of pest behavior is essential for designing a pest control strategy. The life cycle of $\boldsymbol{D}$. speciosa was studied in natural and artificial diets. On the natural diet, corn seedlings were used to feed the larvae and bean leaves for the adults. The artificial diet was adequate for complete development of $D$. speciosa but its life cycle was longer when compared with the natural diet. D. speciosa showed three instars in both diets. Females reared on the natural diet showed higher fecundity. The egg laying rhythm was similar in both diets; the oviposition occurred mainly during the day between 2 and $6 \mathrm{pm}$. Egg hatching was not 
affected by photoperiod. There was an inverse relationship between life cycle lenght and temperature increases from 18 to $32^{\circ} \mathrm{C}$. The temperature threshold was very similar in all stages of $D$. speciosa life cycle. There was a strong preference for the females to lay eggs in organic and dark soils ('Terra Roxa Estruturada Distrófica"), and they preferred to oviposit in wet soils (between 26 to $63 \%$ humidity) to drye ones. Corn was the most attractive host for egg laying by $\boldsymbol{D}$. speciosa followed by bean and soybean plants. Among the substrates tested, the black and green cheese cloth were the best for egg laying by corn rootworm. Adults of $D$. speciosa were more attracted to UV and blue lights. The rearing techniques described herein were adequate for studying the life cycle of $D$. speciosa, and can be used in a mass rearing program of this pest with small adaptations. . The knowledge of the temperature threshold for the egg stage $\left(11,1^{\circ} \mathrm{C}\right)$ can be useful to storage eggs in mass rearing programs of the corn rootworm. 


\section{INTRODUÇÃO}

A espécie Diabrotica speciosa (Germar, 1824) (Coleoptera: Chrysomelidae) é uma praga polífaga, de ampla disseminação nos Estados brasileiros e alguns países da América do Sul (KRYSAN, 1986). Nos últimos anos, em algumas regiões produtoras do Brasil, têm-se registrado perdas significativas na produção de milho devido ao ataque de larvas desta espécie ao sistema radicular. A população de adultos, observada no campo, nas culturas de feijão e de soja é abundante, obrigando os agricultores a realizarem freqüentes pulverizações com inseticidas, no sentido de minimizar o problema. Alguns fatores como: sistemas de produção do milho, novos híbridos, manejo do solo, rotação com outras culturas, baixo índice de parasitismo e a proibição de inseticidas clorados para aplicação no solo, foram determinantes no desenvolvimento e adaptação da praga à cultura do milho ao longo do tempo.

No Brasil, ainda não se tem quantificado os prejuizos que esta praga causa às lavouras, e os técnicos e agricultores não têm consciência da 
sua verdadeira importância em nossas condições. Nos EUA, segundo KAHLER et al. (1985), algumas espécies do gênero Diabrotica, consideradas como as principais pragas do milho naquele país, causam um decréscimo na produção na ordem de 13,5\%. METCALF (1986) estimou em 1 bilhão de dólares/ano os gastos com aplicações de inseticidas e as perdas na produção devido a este grupo de insetos.

Em países da América Central e do Sul, são escassos os trabalhos com as diferentes espécies de Diabrotica, embora sejam referidas como pragas importantes nas culturas do feijão e do milho, principalmente. Tal fato, deve-se ao maior grau de dificuldade para se trabalhar com pragas de hábito subterrâneo, exigindo-se metodologias diferenciadas e adaptadas às condições dos insetos.

O trabalho teve por objetivo estudar o ciclo biológico de $D$. speciosa em dietas natural e artificial; avaliar a influência da temperatura e respectivas exigências térmicas no desenvolvimento das diferentes fases do ciclo biológico do inseto; verificar a influência de alguns fatores bióticos e abióticos no comportamento de oviposição, além de desenvolver e aperfeiçoar uma técnica de criação de $D$. speciosa em laboratório. 


\section{REVISÃO DE LITERATURA}

A espécie Diabrotica speciosa (Germar, 1824) ocorre comumente em países da América do Sul, tendo sido referida no Paraguai por BERTONI (1919), na Argentina por CHRISTENSEN (1944) e RAMALLO \& WEEHT (1976) e no Peru por JAVIER \& PERALTA (1976) e ARESTEGUI (1977). No Brasil, a partir da década de 1920, a presença de adultos de $D$. speciosa, popularmente conhecidos como "vaquinhas", foi referida em quase todos os Estados brasileiros, notadamente atacando a parte aérea das diferentes espécies de plantas cultivadas. Devido ao desconhecimento do seu ciclo biológico, poucos autores se referem aos danos causados por larvas ao sistema radicular das plantas. Embora a espécie $D$. speciosa tenha sido citada como praga do milho há muito tempo por BERTELS (1956), SILVA et al. (1968), BERTELS (1974) e GALLO et al. (1978), as informações mais detalhadas dos danos e dos sintomas causados pelo ataque de larvas ao 
sistema radicular do milho foram somente fornecidas mais recentemente por GASSEN (1986).

Nos EUA, algumas espécies de crisomelídeos pertencentes ao gênero Diabrotica, são consideradas como as principais pragas da cultura do milho. Segundo KRYSAN (1986), as espécies dividem-se em dois grupos: 1) Grupo fucata, representado pelas espécies: Diabrotica balteata, Diabrotica undecimpunctata undecimpunctata e Diabrotica howardi, consideradas espécies multivoltinas e migrantes; 2) Grupo virgifera, representado pelas espécies: Diabrotica virgifera virgifera e Diabrotica virgifera zeae, consideradas espécies univoltinas apresentando diapausa no inverno, na fase de ovo. A espécie $D$. speciosa foi classificada, pelo referido autor, como pertencente ao grupo fucata, embora não ocorra naquele país. Segundo BRANSON \& KRYSAN (1981), esta separação em grupos distintos é atribuída diretamente a disponibilidade estacional de plantas hospedeiras e, indiretamente, ao tipo de clima.

2.1. Biologia e criação de $D$. speciosa em dieta natural

2.1.1. Fase de ovo

2.1.1.1. Coleta, desinfestação superficial e sobrevivência 
São poucos os trabalhos sobre o ciclo biológico e os métodos de criação de $D$. speciosa. COSTA (1954) relatou, pela primeira vez, que as fêmeas colocavam os ovos junto às plantas, logo abaixo da superficie do solo ou em fendas.

HAJI (1981), estudando o ciclo biológico de D. speciosa, em condições de laboratório, verificou que as fêmeas depositavam os ovos em papel de filtro úmido, peciolos, folhas de batatinha e paredes do vidro da gaiola; depois os ovos eram tratados com hipoclorito de sódio $(0,005 \%)$, colocados em placas de Petri e incubados à temperatura ambiente. A viabilidade dos ovos observada, por esta autora, foi de 29,7\%. CARVALHO \& HOHMANN (1982) constataram que, em condições de temperatura ambiente próximas de $25^{\circ} \mathrm{C}$, o período de incubação era de 6,4 dias, com $76,8 \%$ de viabilidade. MILANEZ (1988) utilizou como substrato de oviposição solo úmido e fez o tratamento dos ovos com uma solução de sulfato cúprico (1\%). SILVA-WERNECK et al. (1995), trabalhando com câmara climatizada ajustada às condições de $26 \pm 2^{\circ} \mathrm{C}$, UR de $70 \pm 10 \%$ e fotofase de 14 horas, obtiveram ovos de D. speciosa utilizando-se como substrato de oviposição placas de Petri, contendo areia autoclavada coberta por papel de filtro e gaze preta umedecida. Nestas condições, o período médio de incubação foi de 8,12 dias e a viabilidade média de $63,17 \%$. 
Segundo CHALFANT \& MITCHELL (1967) e KIRK et al. (1968), as espécies de crisomelídeos $D$. howardi e $D$. v. virgifera, preferem ovipositar em substratos úmidos de coloração escura e textura grosseira. No entanto, sem chance de escolha, as referidas espécies podem ovipositar em diferentes materiais que retenham umidade, como papel borrão, gaze e algodão. SCHALK (1986), trabalhando com a espécie $D$. balteata, utilizou como local para oviposição placas de Petri contendo papel absorvente de algodão ou areia, cobertas com uma camada de papel de filtro e três camadas de gaze. $O$ conjunto era mantido úmido e coberto com papel aluminio, para que as fêmeas tivessem uma espécie de refúgio e realizassem a postura. Depois, a gaze, contendo os ovos, era mergulhada em um recipiente com água e agitada para que os ovos se desprendessem, sendo recolhidos em um pano tipo musselina. Finalmente, os ovos eram tratados por 15 minutos em uma solução de hipoclorito de sódio $(0,05 \%)$, lavados em água corrente e colocados em um recipiente contendo areia esterilizada para o desenvolvimento embrionário.

\subsubsection{Exigências térmicas e armazenamento de ovos}

O armazenamento de ovos de insetos visa a continuidade da criação em períodos críticos, por exemplo na entressafra, quando os insetos não estão disponíveis no campo. Alguns autores estudaram 
métodos de se armazenarem ovos de Diabrotica spp. no limite térmico inferior de desenvolvimento (temperatura base). Assim, CHIANG \& SISSON (1968) e WILDE (1971) determinaram que a temperatura base (Tb) para as espécies Diabrotica longicornis e Diabrotica virgifera era próxima de $10^{\circ} \mathrm{C}$, sendo a constante térmica (K) de 368 a 396 graus-dia para o completo desenvolvimento embrionário da espécie $D$. longicornis. A partir destes resultados, PALMER et al. (1977), trabalhando com a especie $D$. virgifera, relataram que a viabilidade dos ovos foi mantida, por um período de $\mathbf{3 0}$ dias, armazenando-os à $10^{\circ} \mathrm{C}$ em meio aquoso contendo ágar $(0,125 \%)$. BRANSON (1978) verificou que os ovos de $D$. virgifera podiam ser armazenados à $10^{\circ} \mathrm{C}$ por 52 semanas, sem perda de viabilidade com relação à testemunha $\left(25^{\circ} \mathrm{C}\right)$. LEW \& JACKSON ${ }^{1}$ constataram que ovos de 1 a 3 dias de idade da espécie Diabrotica undecipunctata howardi, armazenados por um período superior a 4 semanas, à temperatura entre 9 e $12^{\circ} \mathrm{C}$, mantiveram uma viabilidade de $80 \%$. Segundo JACKSON (1985) ovos de Diabrotica spp. são convenientemente armazenados em solos argilosos, com partículas menores que $0,18 \mathrm{~mm}$, à temperatura de $8 \pm 0,5^{\circ} \mathrm{C}$, por um período superior a 5 meses. SCHAAFSMA et al. (1991) desenvolveram um modelo para previsão de eclosão de larvas de $D$. $v$. virgifera, em condições de campo, baseando-se nas exigências térmicas da fase de ovo pós-diapausa, e concluíram que o desenvolvimento era linear,

\footnotetext{
'LEW, A. C. \& JACKSON, J. J. Effect of temperatures on egg viability of southern corn rootworm (Coleoptera: Chrysomelidae) (Em elaboração).
} 
na faixa de temperatura de 16 a $28^{\circ} \mathrm{C}$, sendo $10,5 \pm 0,1^{\circ} \mathrm{C}$ a temperatura base, resultando em uma constante térmica de $258 \pm 3$ graus dia. LEVINE et al. (1992), trabalhando com a espécie D. v. virgifera, no Estado de lllinois (EUA), determinaram que a Tb e a constante térmica $(K)$ foram de $12,7^{\circ} \mathrm{C}$ e 209,7 graus-dia, respectivamente. Os valores encontrados diferem daqueles obtidos por WILDE (1971), que trabalhou com uma população de D. virgifera no Estado de Minnesota (EUA), sugerindo que existe uma significativa diferença fisiológica entre as populações estudadas, nas diferentes áreas geográficas. FISHER et al. (1994) verificaram que ovos de D. barberi, poderiam ser armazenados por um período de 180 dias em temperaturas que variavam entre $9-12^{\circ} \mathrm{C}$, com viabilidade de $60 \%$.

\subsubsection{Fase larval}

A criação de larvas é considerada a fase crítica para a manutenção de colônias de Diabrotica spp. em laboratório, devido principalmente à grande mortalidade de larvas recém-eclodidas, causada por condições desfavoráveis no seu ambiente de desenvolvimento, como o excesso ou falta de umidade, contaminação por fungos e toxicidade dos produtos químicos utilizados para tratar as sementes servidas como fonte de alimentação. 
Segundo BRANSON \& ORTMAN (1967), plântulas de milho são os melhores substratos para a criação de larvas de Diabrotica spp. JACKSON (1986) descreveu, de maneira detalhada, um método de criação para as espécies $D$. virgifera $e$ D. undecimpuctata. howardi, onde 0 desenvolvimento larval se dava em duas etapas. Na primeira etapa, as larvas recém-eclodidas eram colocadas em um recipiente contendo milho pré germinado (com $4 \mathrm{~cm}$ de raízes seminais) e deixadas por sete dias. $\mathrm{Na}$ segunda etapa, as larvas eram colocadas junto ào segundo recipiente, também com milho germinado, para que elas, per si, mudassem de alimento e completassem o ciclo. As condições de laboratório utilizadas eram: 30100 "footcandles" de luminosidade, fluxo de ar menor que $10 \mathrm{ft}^{3} /$ minuto, UR entre $50-60 \%$ e temperatura próxima de $25{ }^{\circ} \mathrm{C}$. BRANSON et al. (1988) aperfeiçoaram o método descrito por JACKSON (1986), colocando os ovos em contato direto com as raízes do milho e eliminando o manuseio de larvas recém eclodidas, havendo uma maior sobrevivência em relação ao método anterior, ou seja de $53 \% \pm 5,0$ de adultos a partir de ovos, de $72,7 \% \pm 10,2$ de adultos a partir da fase larval.

HAJI (1981) criou larvas de D. speciosa utilizando como fonte de alimento inicial plântulas de milho, transferindo, após oito dias, as larvas para tubérculos enraizados de batatinha. A duração média da fase larval observada foi de 35,82 dias. CARVALHO \& HOHMANN (1982) criaram larvinhas de $D$. speciosa em raizes de plântulas de milho e observaram que 
a duração média da fase larval foi de 12,10 dias, compreendendo 3 ínstares, com duração média de 5,3; 2,9; e 3,9 dias, respectivamente. Para cada ínstar, a largura média da cápsula cefálica foi de: 0,$23 ; 0,35$ e 0,57 mm. SILVA-WERNECK et al. (1995) criaram larvas de D. speciosa em condições idênticas às citadas no trabalho anterior e verificaram uma duração média da fase larval de $\mathbf{2 6 , 2 0}$ dias, constatando três ínstares com duração média de 6,33; 4,04 e 8,78 dias, respectivamente. As médias das

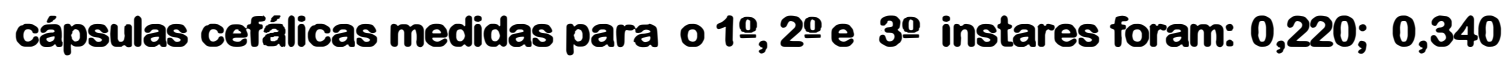
e $0,482 \mathrm{~mm}$, respectivamente.

GONZALEZ et al. (1982) estudaram o ciclo biológico da espécie $D$. balteata, considerada praga importante da cultura do milho e do feijão na Colômbia. As larvas, alimentadas com milho germinado, apresentaram três ínstares larvais com duração média de 3,7; 3,0 e 7,3 dias, sendo que as médias das cápsulas cefálicas foram: 0,$24 ; 0,36$ e $0,53 \mathrm{~mm}$, respectivamente.

JACKSON \& ELLIOTT (1988) estudaram a influência da temperatura no desenvolvimento larval da espécie $D$. $v$. virgifera, e verificaram que a temperatura base $(\mathrm{Tb})$ era de $9^{\circ} \mathrm{C}$, sendo que as larvas se desenvolviam de maneira satisfatória em temperaturas na faixa de 21 a $30^{\circ} \mathrm{C}$, enquanto que temperaturas superiores a $33^{\circ} \mathrm{C}$ impossibilitavam a complementação do $2^{\mathrm{o}}$ instar larval. 
2. 1. 3. Fase pupal

Os crisomelídeos, após completarem a fase larval, se dirigem ao solo onde constroem uma espécie de câmara para se transformarem em pré-pupa e pupa. Segundo JACKSON (1986), a sobrevivência das pupas é afetada quando elas são retiradas da câmara pupal, sofrendo a influência direta das condições do ambiente. Além do solo, outros materiais como areia, vermiculite e turfa podem ser utilizados como meio para pupação, sendo que a umidade do solo deve ficar em torno de $10-20 \%$ antes do ponto de saturação.

HAJI (1981) mencionou que, embora não tenha estudado detalhadamente as fases de larva e de pupa da espécie $D$. speciosa, devido à dificuldade de manuseio, o período de duração da fase pupal foi de 5 a 10 dias, com média de 7,4 dias. CARVALHO \& HOHMANN (1982) relataram que $D$. speciosa teve a duração média de 4,5 dias para a fase de pré-pupa e 6,7 dias para a fase de pupa, enquanto que SILVA-WERNECK et al. (1995) referiram que a duração média das fases de pré-pupa + pupa foi de 7,05 dias. Segundo GONZALEZ et al (1982), a pré-pupa de $D$. balteata caracteriza-se por tomar uma forma de "cajado", no final da fase. A duração média da fase de pré-pupa foi de 4,8 dias e a de pupa de 6,9 dias. KRYSAN (1986) cita que é possível a identificação dos sexos na fase de pupa das espécies de Diabrotica, devido a fêmea apresentar um par de 
papilas na parte ventral junto ao ápice do abdômen, enquanto que no macho esta estrutura é ausente.

\section{1. 4. Fase adulta}

Segundo JACKSON (1986), as condições do laboratório podem influenciar a longevidade e a fertilidade de algumas espécies de Diabrotica. Desta maneira, recomenda-se que a temperatura da sala de criação deve estar próxima de $25 \pm 2^{\circ} \mathrm{C}$ e a UR da gaiola de criação devese manter no intervalo de $30-60 \%$. A UR acima de $60 \%$ pode causar diversos tipos de doença nos adultos e abaixo de $30 \%$, reduz a produção de ovos e a sobrevivência. Segundo o autor, a fertilidade foi satisfatória, quando o espaço interno da gaiola foi maior que $30 \mathrm{~cm}^{2}$ ladulto. A influência do fotoperíodo ainda não foi devidamente estudada; no entanto, fotofase de 12 a 14 horas é comumente utilizada em criações de algumas espécies de Diabrotica.

HAJl (1981) verificou que a manutenção de adultos de $D$. speciosa, alimentados com folhas de soja e feijão, em gaiolas de vidro $(13 \mathrm{~cm}$ de diâmetro $\times 8 \mathrm{~cm}$ de altura), vedadas com tecido de náilon, foi inadequada e com elevada mortalidade. Tal fato, não ocorreu quando os adultos foram alimentados com folhas de batatinha. Nestas condições, os periodos médios de pré-oviposição e oviposição observados foram de 9,68 e 8,99 
dias, respectivamente, com uma produção média de 419,57 ovos/fêmea. A longevidade média dos machos foi de 50,52 dias e das fêmeas de 56,26 dias. CARVALHO \& HOHMANN (1982) criaram adultos de D. speciosa em placas de Petri, alimentando-os com foliolos de feijoeiro e verificaram que o periodo médio de oviposição foi de 5,4 dias, com média de 143,7 ovos/fêmea. A longevidade média observada para os adultos foi de 14,6 dias e a razão sexual de 0,5. SILVA-WERNECK et al. (1995) criaram a espécie $D$. speciosa, em gaiolas cilíndricas de acrílico $(13,5 \mathrm{~cm}$ de altura e $13 \mathrm{~cm}$ de diâmetro) com tampa telada, em foliolos de feijoeiro, e obtiveram os seguintes dados: período médio de pré-oviposição de 9,75 dias; período médio de oviposição de 16,60 dias; número médio de ovos/fêmea de 384,60 士 294,70; longevidade média do macho de 31,6 dias e da fêmea de 26,6 dias, sendo a razão sexual igual a 0,525.

Segundo CUTHEBERG JR. \& REID JR. (1964) e BARTELD \& CHIANG (1977), fêmeas de D. balteata e D. v. virgifera cessam a produção de feromônios após a primeira cópula, não sendo mais atrativas para uma segunda cópula. BRANSON et al. (1977) observaram que machos da espécie D. virgifera copularam, em média, 8,2 vezes durante sua vida $(41,6$ dias, em média), enquanto que a maioria das fêmeas copularam uma única vez, sendo que a segunda cópula se deu apenas durante o período de préoviposição. LEW \& BALL (1980), trabalhando com a mesma espécie, constataram que o número de espermatóforos contidos na espermateca 
era proporcional ao tempo de duração da cópula, podendo durar 3 ou 4 horas, sendo que os espermatóforos inseminados nas fêmeas se degeneravam e desapareciam em 7 dias, enquanto que os espermatozóides conservavam-se viáveis por cerca de 40 dias. SHERWOOD \& LEVINE (1993) observaram que o desevenvolvimento dos ovários de D. v. virgifera, estava relacionado com o tempo de duração da cópula e a presença de espermatóforos na espermateca, o que ocorria após 2 horas de cópula. Fêmeas que copulavam por um período de 1 hora ou não copulavam, tinham seus ovários com dimensões reduzidas e raramente ovipositavam.

\subsection{Biologia e criação de D. speciosa em dieta artificial}

Devido às dificuldades na criação, em larga escala, de Diabrotica spp. em alimentos naturais e, principalmente, em virtude da alta mortalidade larval por contaminação e excesso de manuseio, SUTTER et al. (1971) desenvolveram uma dieta artificial para criação de larvas da especie D. u. howardi, a partir de pequenas modificações da dieta, à base de germe de trigo, proposta, inicialmente, por ADKISON et al (1960), utilizada para a criação da lagarta rosada (Pectinophora gossypiella). ROSE \& MCCABE (1973) modificaram a dieta proposta por SUTTER et al. (1971) retirando a caseína, a sacarose e o colesterol e adicionando germe de trigo $O$ óleo de linho foi substituído pelo óleo de milho (Mazola) e 
adicionou-se a mistura vitamínica de Vanderzant. Com esta modificação, houve um aumento de $14,2 \%$ na viabilidade das larvas de primeira geração, criadas em condições artificiais, quando comparadas com as larvas criadas com alimentação natural. MARRONE et al. (1985) verificaram que os ovos constituiam-se na fonte de contaminação por bactérias em criações em dietas artificiais de $D$. undecimpunctata howardi, tendo solucionado o problema tratando-os com Clorox 1\% por 5 minutos, depois lavando-os com água destilada e, por último, um tratando-os com ácido peracético $(0,25 \%)$ por 2 minutos.

2.3. Influência de fatores abióticos e bióticos na biologia dos crisomelídeos

Devido ao hábito de muitas espécies de crisomelídeos (Galerucinae) realizarem postura no solo e aí completarem seu ciclo, o comportamento dos adultos e as viabilidades das fases de ovo, larva, prépupa e pupa são diretamente influenciados por fatores físicos, químicos e biológicos que atuam no solo, refletindo na abundância destas populações.

2.3.1. Influência das propriedades do solo na oviposição 
GEORGE \& ORTMAN (1965) verificaram que, em condições de laboratório, $D$. virgifera ovipositava em qualquer material úmido colocado na gaiola, mas preferia colocar os ovos em solos com fissuras. CHALFANT \& MITCHEL (1967) testaram solos com partículas de diâmetros variáveis para avaliar a oviposição de $D$. u. howardi, em laboratório, e constataram que havia preferência por solos com partículas de diâmetro maior. KIRK et al. (1968), verificaram que, em condições de campo, a espécie D. virgifera costumava ovipositar em solos que apresentavam fissuras, após chuvas ou irrigação. TURPIN et al. (1972) verificaram que dentre os muitos fatores que influenciavam a oviposição de Diabrotica spp. no solo, os fatores mais importantes eram: percentagem de argila, teores de potássio (correlação positiva) e fósforo (correlação negativa), declividade, drenagem, data de semeadura e população de plantas. MARRONE \& STINNER (1983a) verificaram que o crisomelídeo Cerotoma trifurcata preferia ovipositar em solos orgânicos, seguidos dos solos tipos barro argilo arenoso e arenoso barrento (com umidade acima de $100 \mathrm{mb}$ ), sendo que os solos escuros foram preferidos para oviposição desta espécie, que evitou colocar ovos em solos secos. Segundo Deitz et al. ${ }^{2}$, citado por MARRONE \& STINNER (1983a), foi observado que a população

\footnotetext{
${ }^{2}$ DEITZ, L. L.; VAN DUYN, J. W.; BRADLLEY JR, J. R.; RABB, R. L.; BROOKS, W. M. ; STINNER, R.E. A guide to the identification and biology of soybean arthropods in North Carolina. Releigh, North Caroline Experimental Estation, 1976. 26 p. (Techinical Bulletin, 238).
} 
de C. trifurcata era mais abundante no Estado da Carolina de Norte (EUA), em regiões que predominavam solos com altos teores de matéria orgânica.

MARRONE \& STINNER (1983b) quantificaram os efeitos da umidade, textura e temperatura do solo sobre ovos de $C$. trifurcata em diferentes estágios de desenvolvimento. Assim, a incubação foi estudada em solos arenoso barrento, argiloso-arenoso e orgânico com diferentes teores de umidade, variando da condição de solo muito úmido (saturado) ao solo muito seco. Os autores concluíram que os ovos foram menos sensiveis após terem absorvido água, e que a incubação foi dependente de um limite de umidade crítico para cada tipo de solo. 0 desenvolvimento embrionário cessou quando os ovos foram colocados em solo seco, e a viabilidade foi dependente do tempo de exposição nas diferentes umidades estudadas, sendo maior em solo orgânico saturado, decrescendo com o aumento de temperatura e da profundidade do solo, inferindo que a aeração foi um fator limitante para a viabilidade dos ovos. WEISS et al. (1983), estudando a distribuição espacial de ovos das espécies Diabrotica longicornis barberie D. v. virgifera constararam que, em áreas irrigadas, $80 \%$ dos ovos encontravam-se nos primeiros $10 \mathrm{~cm}$ de profundidade do solo, enquanto que em áreas não irrigadas os ovos foram encontrados em profundidade de até $35 \mathrm{~cm}$. BRUST \& HOUSE (1990 a) observaram que $91 \%$ dos ovos, colocados por D. u. howardi, localizavam-se a $3 \mathrm{~cm}$ do colmo das plantas, 
preferindo ovipositar em solos com maiores teores de umidade, argila e matéria orgânica.

\subsubsection{Influência de plantas hospedeiras na oviposição}

KIRK et al. (1968), observaram que, em condições de campo, a espécie $D$. virgifera concentrava seus ovos junto à gramínea rabo de raposa (Setaria spp.). BRANSON \& ORTMAN (1970) testaram 44 espécies de gramíneas, tidas como plantas hospedeiras de $D$. virgifera, e verificaram que em apenas 13 espécies, foi possível o inseto completar o seu ciclo biológico, sendo o milho a planta hospedeira favorita. SHAW et al. (1978) constataram que os danos causados em milho, por larvas das espécies $D$. longicornis e $D$. virgifera, foram insignificantes em áreas em que o milho foi semeado após a cultura da soja, livre de ervas daninhas hospedeiras e de milho espontâneo. Tal constatação, serviu como base. para controle da praga. HILL \& MAYO (1980) observaram que as espécies D. longicornis e D. virgifera, possuem comportamentos de oviposição distintos. A primeira espécie, é mais abundante em lugares mais elevados e costuma migrar da cultura do milho para outras áreas cultivadas com soja e áreas com restolho de aveia, onde ovipositam. A segunda espécie, é mais abundante em lugares mais baixos e migram somente entre campos cultivados com milho. 
JOHNSON \& TURPIN (1985) relataram que a gramínea rabo de raposa (Setaria spp.) não exerceu influência relevante na atratividade e oviposição de algumas espécies de Diabrotica, entendendo que a interação de fatores abióticos do solo como umidade e textura foram mais importantes na preferência por oviposição. BRANSON \& KRYSAN (1981) citam que larvas da espécie $D$. virgifera não possuem habilidade para distinguir plantas hospedeiras favoráveis ou não, havendo necessidade de "provar" os alimentos. Neste sentido, é importante o comportamento das fêmeas na oviposição, pois elas é que determinam a seleção hospedeira. Steffey et $\mathrm{al}^{3}(1989)$, citados por LEVINE \& OLOUMI-SADEGHI (1991), constataram que em $\mathbf{9 8 , 8} \%$ das áreas de milho, em rotação com a cultura de soja, não ocorreram danos econômicos causados por larvas de Diabrotica spp. BRUST \& HOUSE (1990b) verificaram que as fêmeas de D. u. howardi, preferiam ovipositar em vasos com plântulas de milho na presença de ervas daninhas de folhas largas, as quais serviam como fonte de alimentação, quando comparado com vasos contendo plântulas de milho na presença de ervas daninhas de folhas estreitas (gramineas) ou em vasos contendo apenas o solo nu. BUNTIN et al. (1994) verificaram que larvas de D. u. howardi, causavam maior dano em plântulas de milho em sistemas de plantio direto com ervilhaca, considerada planta hospedeira

\footnotetext{
${ }^{3}$ STEFFEY, K.; KUHLMAN, D.; KINNEY, K. \& GRAY, M. Management of com research and recomendations . In: AGRICULTURAL PESTICIDE CONFERENCE, 3. Champaign, 1989. Proceedings. Champaign, University of Illinois, 1989. p. 76-92.
} 
atrativa para alimentação e oviposição de adultos da referida espécie, enquanto que em áreas com plantio direto sobre aveia, centeio e trigo os danos foram insignificantes. BOETEL et al. (1992) constataram que, em condições de campo, a população e o número de ovos/amostragem da espécie D. barberi era maior em áreas cultivadas com milho, quando comparadas com outras espécies de plantas hospedeiras, incluindo a soja. CINERESKI \& CHIANG (1968), baseando-se em análises do conteúdo estomacal de fêmeas de $D$. barberi, concluíram que os adultos alimentamse de outras plantas hospedeiras, mas retornam para as áreas cultivadas com milho para ovipositarem.

\subsubsection{Atratividade por cores mono e policromáticas}

As cores policromáticas têm sido muito utilizadas na atratividade e captura de insetos, de modo geral, e combinadas com outras substâncias químicas, como por exemplo os feromônios e cairômonios, podem constituir-se num método de monitoramento e até de controle de algumas pragas. Assim, STEFFEY et al. (1982), relatam que adultos das espécies $D$. barberi e $D$. virgifera, são atraídos por armadilhas adesivas de cor amarela. LADD JR. et al. (1984), estudando diferentes cores associadas com substâncias atrativas, verificaram que as cores amarela e azul foram mais eficazes na captura de adultos, quando comparadas com as cores 
laranja (fluorescente), vermelha e preta. LARA et al. (1976), trabalhando com armadilhas adesivas na cultura de Citrus, verificaram uma maior captura de adultos de $D$. speciosa nas armadilhas de cor amarela, seguida da cor branca.

Com relação à atratividade por luz (cor monocromática), BALL (1982) verificou que adultos da espécie $D$. virgifera, eram mais atraidos por luzes emitidas na região de comprimento de ondas mais longas (amarela, vermelha), em relação às luzes emitidas na região de comprimento de ondas mais curtas, caso da luz ultra-violeta, mais atrativas para os insetos, de modo geral. 


\section{MATERIAL E MÉTODOS}

A pesquisa foi conduzida no laboratório de Biologia de Insetos do Departamento de Entomologia da Escola Superior de Agricultura "Luiz de Queiroz" (ESALQ-USP), em Piracicaba, São Paulo. Os estudos foram desenvolvidos em laboratório mantido à temperatura de $25 \pm 2^{\circ} \mathrm{C}$, umidade relativa de $60 \pm 10 \%$ e fotofase de 14 horas, com a espécie Diabrotica speciosa (Germar, 1824) (Coleoptera : Chrysomelidae).

3.1. Biologia e criação de $D$. speciosa em dieta natural

3.1.1. Coletas de adultos no campo

Para o início dos estudos do ciclo biológico em dieta natural, foram coletados adultos em áreas cultivadas com soja, feijão, alfafa, milho e cucurbitáceas, localizadas no campo experimental da Fundação Faculdade 
de Agronomia "Luiz Meneguel", no município de Bandeirantes-Paraná. A coleta foi feita com rede entomológica e, com auxilio de um aspirador bucal, os adultos foram transferidos para gaiolas de PVC (altura $20 \mathrm{~cm}$ e diâmetro de $10 \mathrm{~cm}$ ) com as extremidades vedadas com pano do tipo "voil". No interior das gaiolas, foram colocadas folhas de plantas hospedeiras para manter a alimentação e garantir a sobrevivência dos insetos durante a viagem para Piracicaba, SP.

Foram avaliados os seguintes parâmetros:

a) Fase de ovo

duração e viabilidade

b) Fase de larva

duração e número de ínstares

c) Fases de pré-pupae pupa

duração

d) Fase adulta

períodos de pré-oviposição e oviposição, fecundidade e longevidade. 
3.1.2. Postura e coleta de ovos em laboratório

Os adultos foram colocados em gaiolas de acrílico de formato retangular $(45 \times 35 \times 35 \mathrm{~cm})$, com duas aberturas laterais $(10 \times 28$ cm), vedadas com tela de náilon, para ventilação. Utilizaram-se, como substrato para oviposição, placas de Petri $(9 \mathrm{~cm}$ de diâmetro $\times 1,5 \mathrm{~cm}$ de altura), contendo areia fina úmida, cobertas com papel de filtro e gase preta umedecida, conforme metodologia de SILVA-WERNECK et al. (1995). Os ovos foram recolhidos mergulhando-se a gaze em um recipiente contendo água destilada e, depois, coando-os em um pano tipo "voil". A seguir, os ovos foram tratados com uma solução de hipoclorito de sódio (0,05\%) por 2 minutos, e transferidos para placas de Petri ( diâmetro $6 \mathrm{~cm} \times$ altura $1 \mathrm{~cm}$ ), forradas com papel de filtro mantido úmido e tampadas para o desenvolvimento do embrião e observação do período de incubação.

\subsubsection{Fase larval}

As larvas, recém-eclodidas, tiveram como substrato alimentar raizes seminais de milho pipoca. Inicialmente, para acelerar o processo germinativo, as sementes foram deixadas submersas em água por 24 horas, e, depois, acondicionadas em bandejas plásticas transparentes $(17 \times 30 \mathrm{~cm})$ (Figura $1 \mathrm{~A})$. As bandejas eram forradas com papel germiteste, 
umedecido com água destilada, e colocadas numa câmara de germinação (temperatura $25^{\circ} \mathrm{C}$ e fotofase de 14 horas). Para evitar a contaminação por fungos, as sementes foram, previamente, tratadas com uma mistura dos fungicidas thiabendazole $(1 \mathrm{~g} / \mathrm{kg}$ de sementes) e captan $(1,5 \mathrm{~g} / \mathrm{kg}$ de sementes). Após o quarto dia de iniciado o processo germinativo, as larvas foram transferidas para as raízes seminais do milho. Foi mantida equivalência de uma semente germinada/larva. Para cada bandeja foi colocada uma população de 150 larvas, trocando-se o alimento, pelo menos, uma vez antes de completarem a fase larval. Para a determinação do número de ínstares, foi medida, diariamente, a largura da cápsula cefálica em amostras de 25 larvas, por meio de uma ocular micrométrica modelo WILD MMS235 acoplada a um microscópio estereoscópico.

\subsubsection{Fases de pré-pupa e pupa}

Ao final do terceiro ínstar, as larvas foram peneiradas (Figura 1B) e transferidas para uma bandeja de pupação $(17 \times 17 \mathrm{~cm})$ contendo duas divisões (Figura 1C). Na primeira divisão, forrada com papel germiteste úmido, foram colocadas sementes germinadas de milho, que receberam as larvas provenientes da bandeja referida na figura $1 \mathrm{~A}$. $\mathrm{Na}$ segunda divisão, foi colocada uma mistura (1:1) de solo e areia fina, mantida úmida. Através dos furos, presentes na parede divisória da 
bandeja, as larvas tiveram acesso ao solo e passaram para as fases de prépupa e pupa. Nesta fase, foi feita a separação de sexos, baseando-se na presença de um par de papilas existente na parte ventral das fêmeas, próximo ao ápice do abdômen (KRYSAN, 1986).

\subsubsection{Fase adulta}

Para a obtenção de dados de longevidade dos adultos e da fecundidade, 20 casais foram individualizados em gaiolas plásticas transparentes de formato cilíndrico, medindo $10 \mathrm{~cm}$ de altura e $10 \mathrm{~cm}$ de diâmetro (Figura 2). Na parede da gaiola existia uma abertura de $1,5 \mathrm{~cm}$ de diâmetro, vedada com pano tipo "voil", para ventilação. Os adultos foram alimentados com folíolos de feijoeiro, mantidos túrgidos através de algodão umedecido no pecíolo. Para a oviposição, foi colocado no interior da gaiola um recipiente de $0,6 \mathrm{~cm}$ de altura e $3 \mathrm{~cm}$ de diâmetro contendo areia fina úmida, coberta por papel germiteste e gaze preta umedecida. Procedimento idêntico ao descrito no item 3.1.2 foi adotado com relação à coleta dos ovos . 

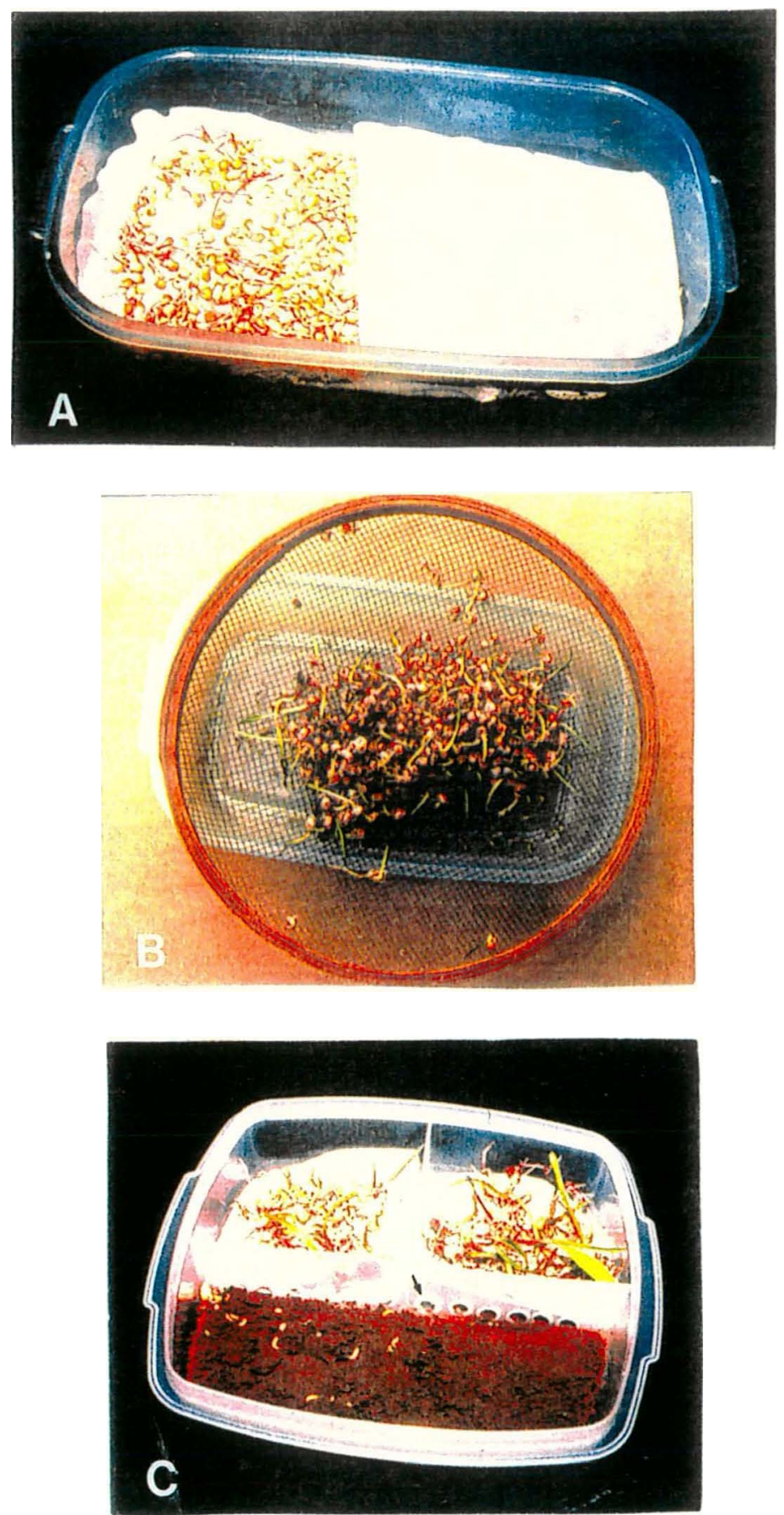

Figura 1. Método de criação de D. speciosa em laboratório. A) bandeja contendo milho germinado; B) peneiramento de larvas de 30 instar; C) bandeja com divisória perfurada dando acesso para as larvas puparem no solo. 


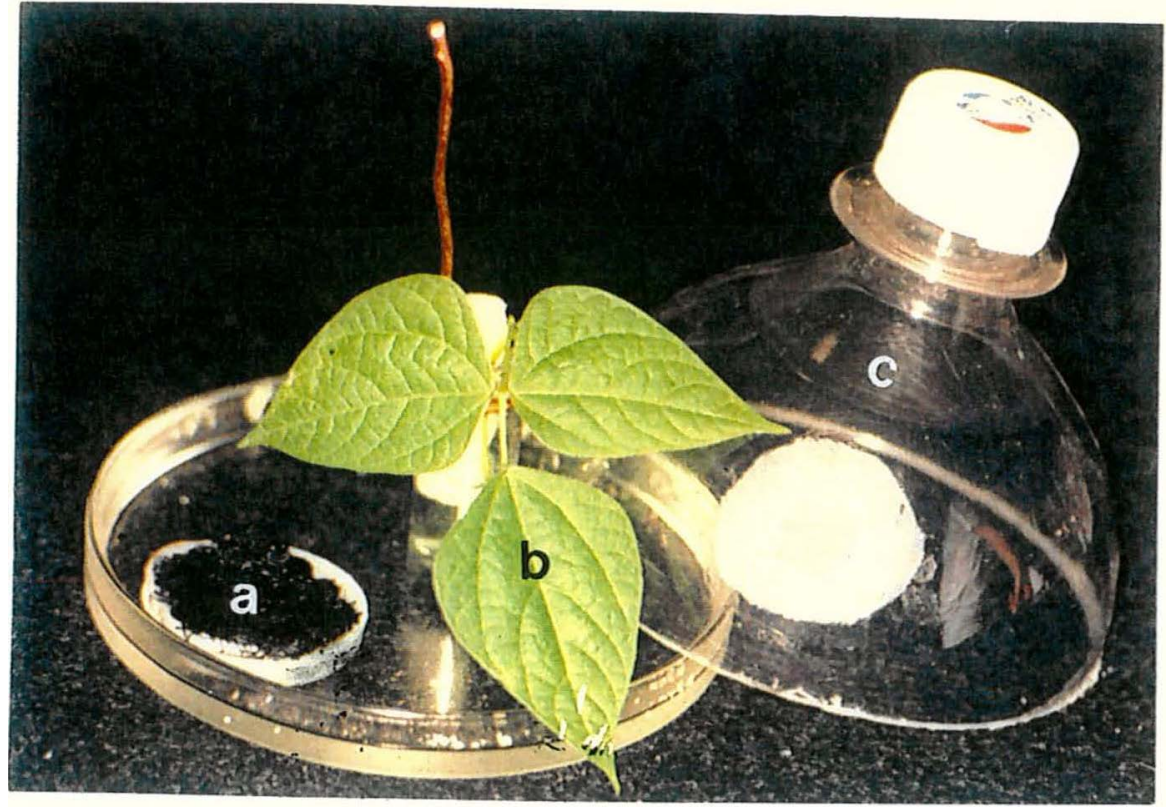

Figura 2. Gaiola para observação da longevidade e fecundidade de adultos de $D$. speciosa. a) gaze preta para postura; b) foliolo de feijoeiro para alimentação; c) tampa transparente da gaiola.

3.2. Biologia e criação de $D$. speciosa em dieta artificial

Para o estudo da biologia $D$. speciosa em dieta artificial, a primeira geração de adultos foi coletada no campo.

Foram avaliados os seguintes parâmetros:

a) fase de larva

duração e número de ínstares 
b) Fases de pré-pupa e pupa

duração

c) Fase adulta

períodos de pré-oviposição e oviposição, fecundidade

e longevidade

3.2.1. Fase larval

Foram comparadas quatro dietas utilizadas rotineiramente no laboratório de Biologia de Insetos do Departamento de Entomologia da ESALQ/USP, para criação de diferentes espécies de Lepidoptera (dietas A, B, C e D) e uma dieta (E) para Coleoptera (Chrysomelidae) (Apêndice 1).

As dietas utilizadas, com os respectivos autores e fontes protéicas, foram as seguintes:

A: BOWLING (1967) à base de feijão e levedura de cerveja ;

B: MIHSFELDT (1985) à base de farinha de milho, germe de trigo e levedura de cerveja;

C: BERGER (1963) à base de germe de trigo e caseína, incluindo celulose;

D: HENSLEY \& HAMMOND (1968) à base de germe de trigo e caseína; 


\section{E: SUTTER et al. (1971) à base de germe de trigo e caseína, incluindo celulose.}

Como recipientes para as dietas foram utilizados copos plásticos de $5,5 \mathrm{~cm}$ de altura e $6 \mathrm{~cm}$ de diâmetro, tampados e contendo $1 / 3$ do seu volume com dieta, suficiente para a complementação da fase larval. Após o resfriamento da dieta, os recipientes foram levados à uma câmara asséptica, provida de lâmpada germicida, pelo período de 1 hora para a esterilização externa. Nesta mesma câmara procedeu-se à transferência das larvinhas recém-eclodidas para os copos com dieta, com o auxilio de um pincel fino. Foram "inoculadas" três larvinhas por recipiente. Para determinação do número de ínstares, mediu-se, diariamente, a largura da cápsula cefálica em amostras de 25 larvas, conforme procedimento citado anteriormente, para o estudo do desenvolvimento larval em dieta natural (item 3.1.3.).

\subsubsection{Fases de pré-pupa e pupa}

Próximo ao final do terceiro instar, as larvas foram transferidas para recipientes plásticos, idênticos aos utilizados para o desenvolvimento larval, contendo um pouco de uma mistura (1:1) de solo e 
areia fina úmida, para transformação em pré-pupa e pupa. Nestes mesmos recipientes, que permaneceram tampados, emergiram os adultos.

\subsubsection{Fase adulta}

Para as observações de longevidade dos adultos, fecundidade e viabilidade dos ovos, o método foi idêntico àquele citado no item 3.1.5.

3.3. Periodicidade de postura de D. speciosa

Estudou-se a periodicidade de postura de D. speciosa proveniente de campo, em condições de laboratório, com fotoperíodo ajustado para 14 horas de luz (fotofase) e 10 horas de escuro (escotofase). Os dados de postura foram tomados avaliando-se o número de ovos colocados nos seguintes intervalos horários: 06-10; 10-14; 14-18; 18-20; 20 $06 \mathrm{~h}$. Como substrato de postura, foram utilizados recipientes contendo gaze preta. Após $24 \mathrm{~h}$, procedeu-se à contagem dos ovos nos respectivos períodos mencionados. Estas observações foram repetidas por cinco dias seguidos. 


\subsection{Influência do fotoperiodo no periodo de incubação e na viabilidade dos ovos de $D$. speciosa}

Devido ao hábito da espécie $D$. speciosa realizar a postura no solo, onde aparentemente não há iluminação, realizou-se um experimento com o objetivo de verificar a influência da exposição dos ovos a dois fotoperíodos, em condições normais de criação do inseto em laboratório. O experimento foi realizado em uma câmara climatizada, mantendo-se a temperatura em $25 \pm 1^{\circ} \mathrm{C}$ e UR de $60 \pm 10 \%$. O delineamento experimental foi inteiramente casualizado com os seguintes tratamentos: 1) fotofase de 14 horas (14: 10) e 2) ausência de luz (0: 24). Cada tratamento teve dez repetições, sendo colocados 20 ovos/ placa de Petri $(9,0 \mathrm{~cm}$ de diâmetro e $1,5 \mathrm{~cm}$ de altura), forradas com papel filtro mantido úmido. Foi observado o período médio de incubação (dias) e a viabilidade (\%) dos ovos.

3.5. Influência de diferentes cores de gaze na oviposição de $D$. speciosa

Foi realizado um teste para avaliar o efeito de diferentes cores de gaze, utilizada como substrato de oviposição em laboratório, na atratividade para postura de $D$. speciosa. Para tanto, gaze de cor branca 
foi tingida com corante de roupas da marca Guarany nas cores vermelha (no 09) e amarela (no 03) e da da marca Tupy nas cores preta (no 36) e verde (n- 20). Os tratamentos constaram das quatro cores citadas incluindo a cor branca. O delineamento experimental foi em blocos casualizados com cinco repetições. As gazes foram dobradas em quatro camadas, colocadas em recipientes plásticos de $5 \mathrm{~cm}$ de diâmetro e $1,5 \mathrm{~cm}$ de altura, e mantidas úmidas. O conjunto de recipientes, ou seja, os diferentes tratamentos, foi colocado no interior da gaiola (citada no item 3.1.2.) e deixado por 24 horas para que as fêmeas realizassem a postura neste tipo de teste de livre escolha. Após este período, os recipientes foram retirados e procedeu-se à contagem dos ovos, conforme métodoldescrito no item 3.1.2.

3.6. Efeito da temperatura e determinação das exigências térmicas do ciclo biológico de D. speciosa.

\subsubsection{Fase de ovo}

Estudou-se o efeito da temperatura no desenvolvimento embrionário de $D$. speciosa. A pesquisa foi conduzida em seis câmaras Climatizadas, reguladas a $18,20,22,25,30$ e $32^{\circ} \mathrm{C}$, UR de $60 \pm 10 \%$ e fotofase de $14 \mathrm{~h}$. $O$ delineamento experimental foi inteiramente casualizado 
com cinco repetições. Foram utilizados cem ovos, divididos em cinco grupos de vinte, e colocados em caixas plásticas $(6,0 \mathrm{~cm}$ de diâmetro $\times 2,0$ cm de altura). Cada caixa plástica foi forrada com papel filtro mantido úmido e vedada com fita adesiva. Os ovos receberam tratamento para desinfecção superficial, através da imersão em solução de hipoclorito de sódio $(0,05 \%)$ por 2 minutos. Após o $5^{\circ}$ dia, as caixas foram abertas diariamente para contagem das larvinhas eclodidas. A partir dos resultados obtidos, foram calculadas as exigências térmicas da fase de ovo, determinando-se a temperatura base (Tb) e a constante térmica (K) pelo método da hipérbole (HADDAD \& PARRA, 1984)

\subsubsection{Periodo larva-adulto}

O método usado foi idêntico àquele citada no item 3.6.1. para o estudo da fase de ovo. O substrato para alimentação das larvas foi raizes de milho germinado. 0 delineamento estatístico foi inteiramente casualizado com cinco repetições. Cada repetição constou de uma bandeja (Figura 1A), inoculada com 50 larvas recém-eclodidas. A temperatura base (Tb) e a constante térmica (K), para o referido período, foram determinadas pelo método da hipérbole ( HADDAD \& PARRA, 1984). 
3.7. Influência de fatores abióticos e bióticos na biologia de $D$. speciosa

3.7.1. Influência do tipo e da umidade do solo na oviposição

Para o estudo da influência do tipo e da umidade do solo na oviposição de $D$. speciosa, foram realizados dois experimentos em laboratório mantido à temperatura de $25 \pm 2{ }^{\circ} \mathrm{C}$, UR $60 \pm 10 \%$ e fotofase de $14 \mathrm{~h}$. Os delineamentos experimentais foram em blocos casualizados repetidos cinco vezes.

EXPERIMENTO 1: Estudou-se, em teste de livre escolha, a preferência para oviposição de $D$. speciosa em quatro tipos de solo: Terra Roxa Estruturada Distrófica, Latossolo Roxo Distrófico, Cambissolo Húmico Álico e Terra Roxa Estruturada Latossólica (Figura 3, Apêndices 2 e 3). Inicialmente, os solos foram peneirados (peneira malha $0,387 \mathrm{~mm}$ ), colocados em copos plásticos de $5,5 \mathrm{~cm}$ de diâmetro e $1,0 \mathrm{~cm}$ de altura, umedecidos até a saturação, e transferidos para o interior de uma gaiola de acrílico de formato retangular ( $45 \times 45 \times 35 \mathrm{~cm})$, onde foram colocados 568 insetos adultos, coletados no campo, e mantidos por 24 horas. Após este periodo, os ovos foram retirados do solo, através de estiletes, e contados. 0 experimento foi repetido no tempo, colocando-se um novo conjunto de 
copos plásticos com solo a cada 24 horas, até completar cinco dias do início do experimento.

EXPERIMENTO 2: Definida a preferência de oviposição pelo tipo de solo Terra Roxa Estruturada Distrófica do Experimento 1, estudou-se a preferência de oviposição de $D$. speciosa, em função da curva de retenção de umidade do referido solo, determinada pelo Laboratório de Física e Meteorologia da ESALQ/USP, através do método de RICHARDS (1965). Desta maneira, com os pontos obtidos na curva $(63,32,29,26,24$ e 22\%) foram definidos os tratamentos estudados no Experimento 2 (Tabela 1). Ajustadas as umidades do solo, o método para a avaliação deste experimento foi idêntico aquele descrito para o Experimento 1, exceto o número de adultos/gaiola, que foi de 438. 


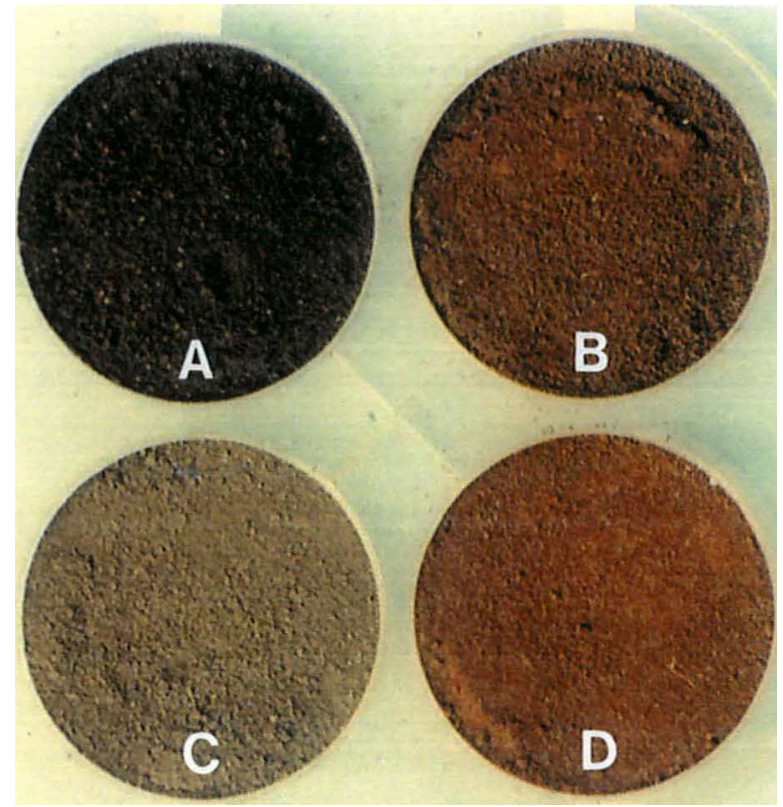

Figura 3.Tipos de solo estudados para avaliar a postura de D. speciosa. A) Terra Roxa Estruturada Distrófica; B) Latossolo Roxo Distrófico; $\begin{array}{llll}\text { C) Cambissolo Húmico Álico; } & \text { D) Terra Roxa Estruturada }\end{array}$ Latossólica 
Tabela 1. Dados da curva de retenção de água (bar) em Terra Roxa Estruturada Distrófica.

\begin{tabular}{ccc}
\hline $\begin{array}{c}\text { Potencial mátrico } \\
(\text { bar })\end{array}$ & Umidade & Umidade do solo \\
\hline 0,64 & $(\mathbf{g} / \mathbf{g})$ & $(\%)$ \\
0,33 & 0.6399 & 64 \\
1,00 & 0,3238 & 32 \\
2,00 & 0,2900 & 29 \\
5,00 & 0,2626 & 26 \\
15,00 & 0,2444 & 24 \\
\hline
\end{tabular}

3.7.2. Influência de plantas hospedeiras na oviposição de D. speciosa

Foi estudada, em teste de livre escolha, a influência das seguintes plantas hospedeiras, semeadas em Terra Roxa Estruturada Distrófica, na oviposição de D. speciosa : milho (pipoca), arroz "IAC-165", feijão "Carioca-80" e soja "BR-37". O delineamento experimental foi em blocos casualizados com cinco repetições, incluindo o solo nu como um tratamento. As plântulas com 15 dias de germinadas, mantidas em copos plásticos (6,0 cm de altura e 5,5 cm de diâmetro) juntamente com o solo nu, 
com umidade ajustada em $63 \%$, foram colocadas no interior de uma gaiola de acrílico, semelhante àquela utilizada nos experimentos 1 e 2 , contendo 226 adultos. Procedimento idêntico dos experimentos 1 e 2 (item 3.7.1.) foi adotado para a avaliação deste experimento.

3.8. Atração de adultos de $D$. speciosa à luzes de diferentes comprimentos de onda

O teste foi realizado em um aparelho de formato hexagonal descrito por BOTELHO et al. (1973) (Figura 4), confeccionado em material galvanizado, no qual das faces do polígono saem tubos com diâmetro de 15 cm e comprimento de $64 \mathrm{~cm}$. Na parte central, existe uma abertura circular para colocação dos insetos. As entradas para os tubos são fechadas por uma placa de vidro que impede os insetos de deixarem a arena. Em cada extremidade dos tubos foram acoplados sacos de polietileno onde foram capturados os individuos atraídos. Preliminarmente, foram testadas 12 lâmpadas modelo F15T8 com as especificações: R (vermelha), DL (luz do dia), G (verde), CG (verde fria), BLB e BL (ultra-violeta), W (branca), PL (luz da planta), G (amarela), B (azul), WW (branca quente) e UBL (ultra-azul), das quais foram selecionadas as 6 lâmpadas mais atrativas. Os experimentos foram delineados em blocos ao acaso com quatro repetições. Para os testes com machos e fêmeas, isolados, foram liberados 50 
individuos por repetição, e para o testes com casais, 100 indivíduos por repetição. O intervalo de tempo para a avaliação dos testes foi de 24 horas, e para a realização das repetições foi de 30 minutos, em média.

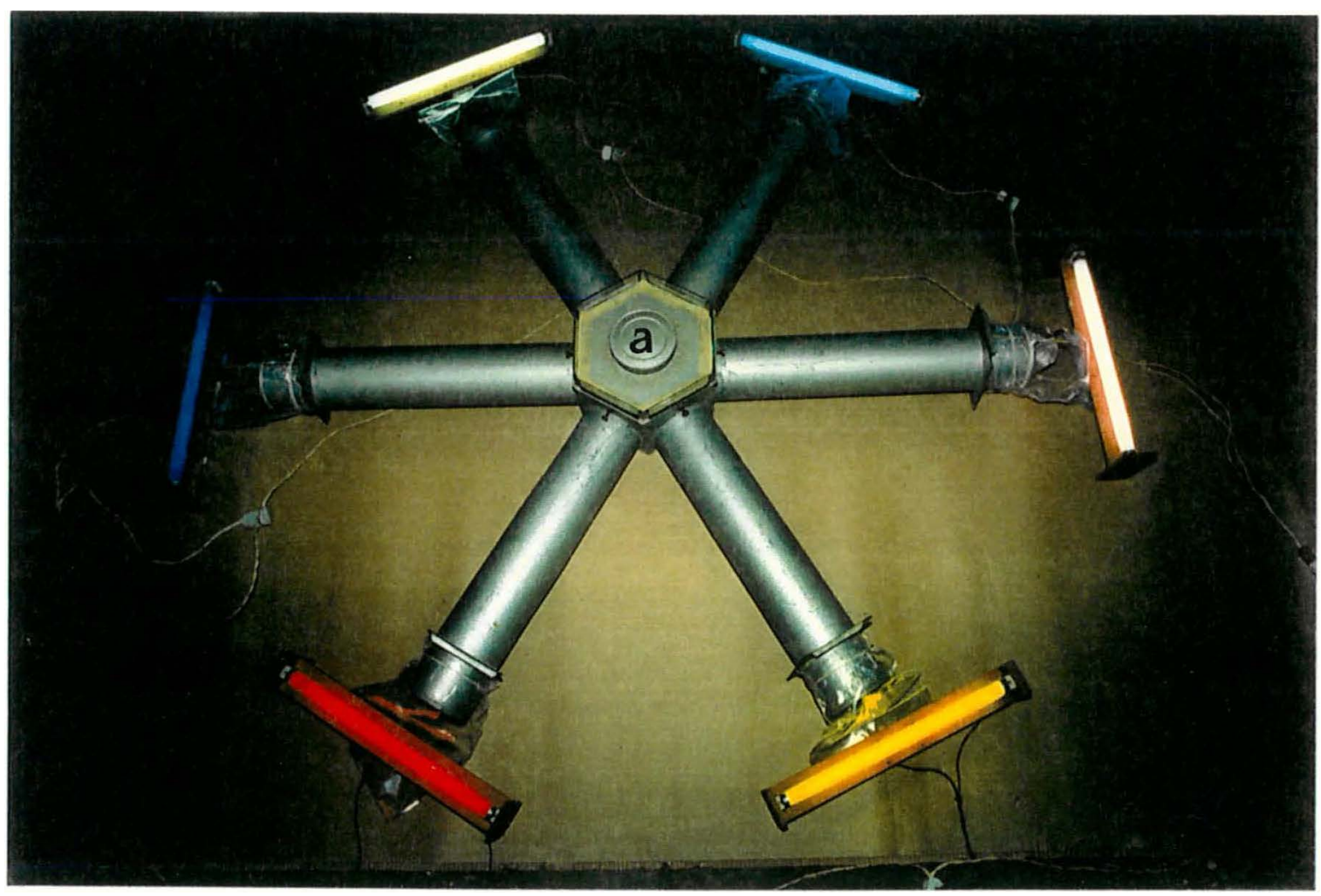

Figura 4. Aparelho para atração de insetos a luzes de diferentes comprimentos de onda (BOTELHO et al., 1973). a) câmara para liberação dos insetos.

3.9. Armazenamento de ovos de D. speciosa

Com o objetivo da criação contínua de $D$. speciosa em condições de laboratório, estudou-se o tempo viável de armazenamento dos ovos, à 
partir de sua temperatura base, que foi calculada conforme descrito no item 3.4. Para tanto, partiu-se de um lote de ovos recém colocados, previamente tratados com uma solução de hipoclorito de sódio $(0.05 \%)$ por dois minutos, os quais foram acondicionados em uma placa de Petri de 9,0 $\mathrm{cm}$ de diâmetro por $2,0 \mathrm{~cm}$ de altura, forrada com papel filtro umedecido e envolta por papel alumínio. Desta maneira, os ovos foram armazenados em uma câmara com temperatura ajustada à temperatura base calculada (3.6.1.). O delineamento experimental foi em blocos casualizados com cinco repetições. Os tratamentos constituiram-se dos seguintes intervalos de tempo de armazenamento: 7, 14, 28, 56 e 112 dias; a testemunha foi a viabilidade obtida a $25 \pm 2^{\circ} \mathrm{C}$; UR de $60 \pm 10 \%$ e fotofase de $14 \mathrm{~h}$, para ovos recém colocados. Cada repetição constou de 100 ovos divididos em cinco grupos de vinte ovos que, nos intervalos de tempo citados, eram colocados em caixas plásticas ( $6,0 \mathrm{~cm}$ de diâmetro $\times 2,0 \mathrm{~cm}$ de altura) forradas com papel filtro mantido úmido. As caixas pláticas eram então e, após, transferidas para uma câmara climatizada (temperatura $25 \pm 2^{\circ} \mathrm{C}$, UR $60 \pm$ $10 \%$ e fotofase de $14 \mathrm{~h}$ ), para registro das respectivas viabilidades. 
3.10. Análises estatística e de sobrevivência de adultos

\section{Diabrotica speciosa}

Foi realizada a análise de variância dos dados obtidos e as médias comparadas pelo teste de Tukey, ao nivel de $5 \%$ de probabilidade. Os dados de sobrevivência dos adultos em dieta natural e artificial, foram submetidos ao ajuste de distribuição de Weibull, conforme SGRILLO (1982). 


\section{RESULTADOS E DISCUSSÃO}

4.1. Biologia de D.speciosa em dietas artificial e natural

Foi estudado o ciclo biológico de Diabrotica speciosa (Germar, 1824) em dietas artificial e natural. As diferentes fases de desenvolvimento, características de um inseto holometabólico, são mostradas na figura 5.

\subsubsection{Duração das fases de larva, pré-pupa e pupa}

Dentre as diferentes dietas testadas, a dieta de BERGER (1963) à base de germe de trigo e caseína, incluindo celulose, utilizada rotineiramente para a criação de Heliothis virescens, foi a única que permitiu o desenvolvimento do inseto, suprindo assim, suas exigêncas nutricionais. Nas demais dietas (BOWLING,1967; MIHSFELDT, 1985; HENSLEY \& HAMMOND, 1968 e SUTTER et al., 1971), a larva não se desenvolveu. Em dieta artificial, a duração do período larva-adulto foi de 
34 dias, enquanto que em dieta natural foi de 29, 2 dias (Tabela 2). Observase, que em dieta artificial houve um acréscimo na duração das fases larval (10, 2o e 3o ínstares ) e de pré-pupa, resultando num ciclo mais longo. Tal fato é compreensivel, se considerarmos que os dados são provenientes da primeira geração do inseto criado em dieta artificial; portanto, é possivel que, em gerações sucessivas de laboratório, seja conseguido um "strain" mais adaptado e com ciclo mais curto, desde que o inseto se alimentou normalmente nesta primeira geração, dando origem a adultos normais (Figura 6). 

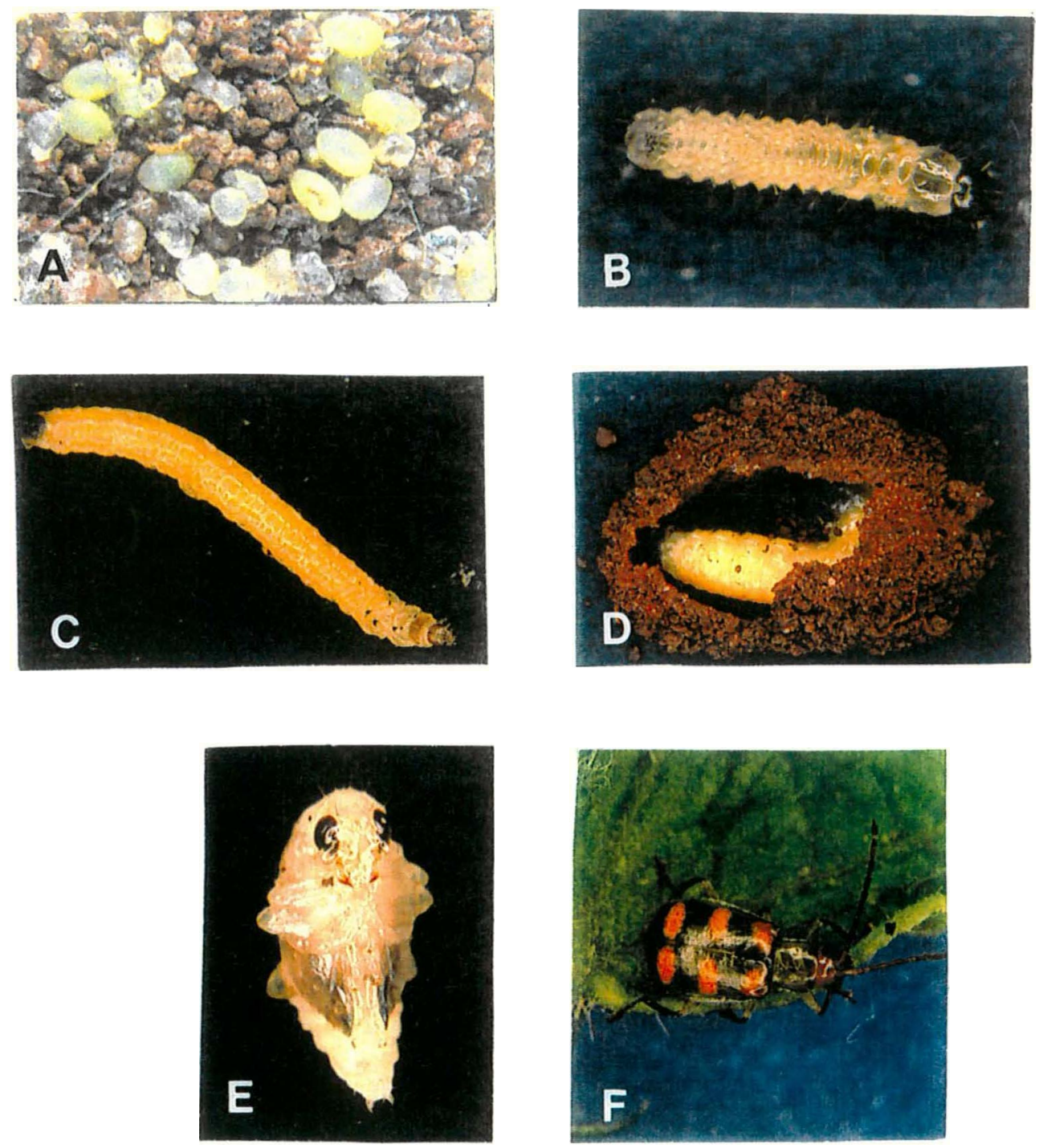

Figura 5. Fases do ciclo biológico de $D$. speciosa. A) ovos; B) larva de 1o instar; C) larva de 3o ínstar; D) pré-pupa; E) pupa; F) adulto. 

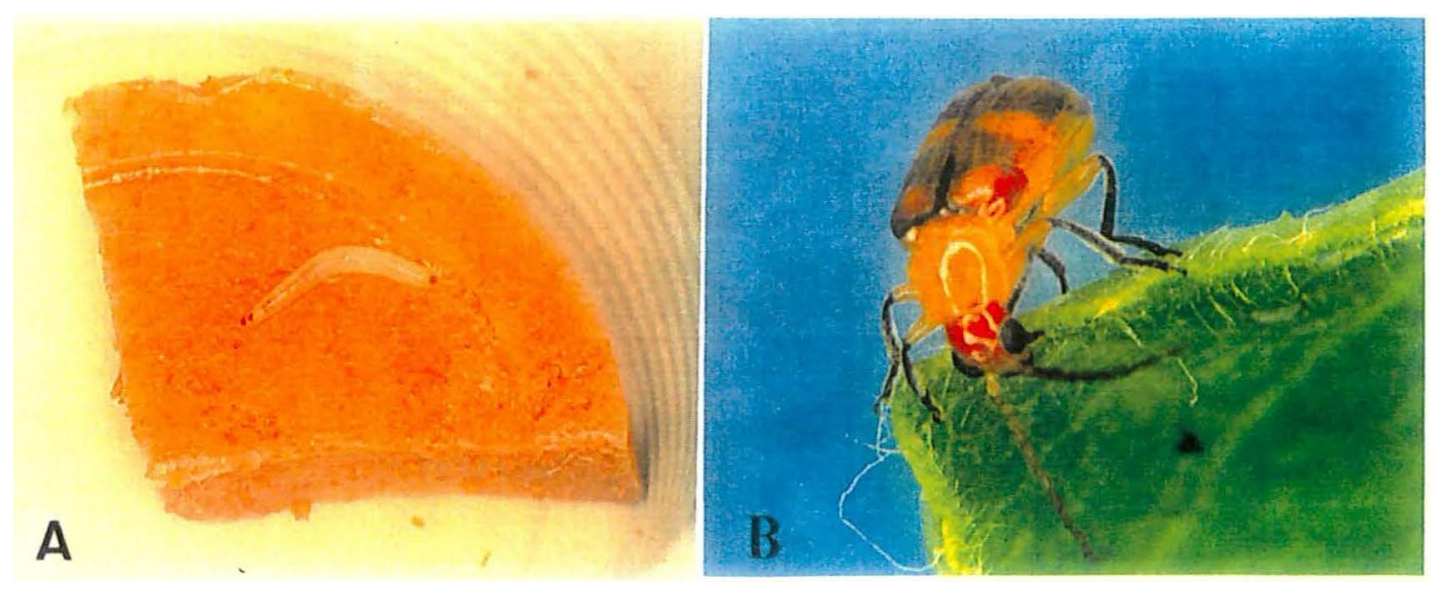

Figura 6. Larva (A) e adulto (B) de D. speciosa criados em dieta artificial.

As dietas de ADKISSON et al. (1960), formulada para a espécie Pectinophora gossypiela, e de BERGER (1963), utilizada para Heliothis virescens, serviram como base para formulações de dietas para muitas espécies de insetos . Assim, SUTTER et al. (1971), baseados na dieta de ADKISSON et al. (1960), desenvolveram uma dieta para a espécie de crisomelídeo D. u. howardi, modificada mais tarde por ROSE \& McCABE (1973), que testada para $D$. speciosa, nesta pesquisa, não permitiu o desenvolvimento. 
Tabela 2. Duração das fases de larva, pré-pupa e pupa de D.speciosa, criada em dietas natural e artificial. Temperatura $25 \pm 2^{\circ} \mathrm{C}$; UR $60 \pm 10 \%$; Fotofase: $14 \mathrm{~h}$.

\begin{tabular}{ccc}
\hline & \multicolumn{2}{c}{ Duração (dias) } \\
Fases & \multicolumn{2}{c}{ Dietas } \\
& Natural & Artificial \\
\hline $1^{\text {o ínstar }}$ & $5,1 \pm 0,7$ & $6,4 \pm 1,4$ \\
2o ínstar & $4,7 \pm 1,1$ & $6,6 \pm 1,1$ \\
3o ínstar & $7,7 \pm 0,6$ & $8,1 \pm 0,4$ \\
Pré-pupa & $4,8 \pm 0,5$ & $6,1 \pm 1,1$ \\
Pupa & $6,9 \pm 0,3$ & $6,8 \pm 1,5$ \\
\hline Total & 29,2 & 34,0 \\
\hline
\end{tabular}

Com relação à dieta natural, o período médio de desenvolvimento larval (17,5 dias) foi inferior aos valores 35,82 e 26,20 dias obtidos por HAJI (1981) e SILVA-WERNECK et al. (1995), respectivamente. É interessante ressaltar que o longo período de 35,82 dias obtido por HAJI (1981) para o desenvolvimento da fase larval de $D$. speciosa, provavelmente deveu-se ao fato do substrato alimentar (tubérculo de batatinha) ter sido menos adequado. Em contraposição, CARVALHO \& HOHMANN (1982) 
citam a duração de 12,10 dias para o período de desenvolvimento larval de D. speciosa, tendo plântulas de milho como substrato alimentar, concordando com BRANSON \& ORTMAN (1967) na afirmação que plântulas de milho são os melhores substratos para criação de larvas de Diabroticaspp.

Devido as fases de pré-pupa e pupa ocorrerem dentro de casulos, formados de solo, é difícil se determinar com precisão, os limites de suas durações. Procurou-se contornar este problema observanda-se diariamente as transformações processadas. Na presente pesquisa, os dados obtidos para a fase de pré-pupa (4,8 dias), em dieta natural, são inferiores aos obtidos para a mesma fase em dieta artificial (6,1 dias), enquanto que para a fase de pupa os valores são bastante próximos nas duas dietas estudadas (Tabela 2). Os valores das fases de pré-pupa e pupa em dieta natural, estão em concordância com aqueles obtidos por CARVALHO \& HOHMANN (1982) para D. speciosa, e coincidentes com valores obtidos para a espécie D. balteata por GONZALEZ et al. (1982).

A razão sexual observada foi $0,50 \mathrm{em}$ dieta natural e $0,52 \mathrm{em}$ dieta artificial. Estes dados estão coerentes com os resultados de CARVALHO \& HOHMANN (1982) \& SILVA-WERNECK et al. (1995). Este resultado demonstra que a dieta artificial testada na presente pesquisa pode ser adequada, desde que afetou igualmente os sexos, mantendo a razão sexual obtida na dieta natural. 
Tanto em dieta natural como artificial, constatou-se a ocorrência de três ínstares com valores de larguras de cápsula cefálicas bem definidas, sendo os dados muito próximos, revelando equivalência na qualidade dos alimentos (Tabela 3, Figuras 7 e 8). Em dieta natural, a razão de crescimento foi de 1,55 do segundo para o primeiro ínstar e de 1,48 do terceiro para o segundo ínstar. Em dieta artificial, estes valores foram, respectivamente, de 1,41 e 1,55. Estes valores estão de acordo com a regra de DYAR (1890), segundo a qual "as cápsulas cefálicas crescem em progressão geométrica, aumentando em largura a cada ecdise, numa razão constante e em média de 1,4", aceitando-se uma variação de 1,1 até 1,9. Esta regra verificada inicialmente para Lepidoptera tem sido adotada para outras espécies de insetos, inclusive Coleoptera (PARRA \& HADDAD, 1989). Os valores obtidos coincidem com os de CARVALHO \& HOHMANN (1982) e os de SILVA-WERNECK et al. (1995) para a espécie D. speciosa, e com os valores registrados para a espécie $D$. balteata (GONZALEZ et al.,1982). 
Tabela 3. Largura média e razão de crescimento de cápsulas cefálicas de D. speciosa, criadas em dietas natural e artificial. Temperatura $25 \pm 2^{\circ} \mathrm{C}$, UR $60 \pm 10 \%$, Fotofase $10 \mathrm{~h}$.

Cápsula cefálica $(\mathrm{mm}) \quad$ Razão de crescimento

\begin{tabular}{ccccc} 
Ínstar & \multicolumn{2}{c}{ Dieta } \\
& Natural & Artificial & Natural & Artificial \\
\hline I & $0,22 \pm 0,01$ & $0,22 \pm 0,02$ & 1,55 \\
II & $0,34 \pm 0,01$ & $0,32 \pm 0,02$ & 1,41 \\
III & $0,51 \pm 0,03$ & $0,50 \pm 0,01$ & 1,48 & 1,55 \\
\hline Médias da razão de crescimento & 1,51 & 1,48 \\
\hline
\end{tabular}




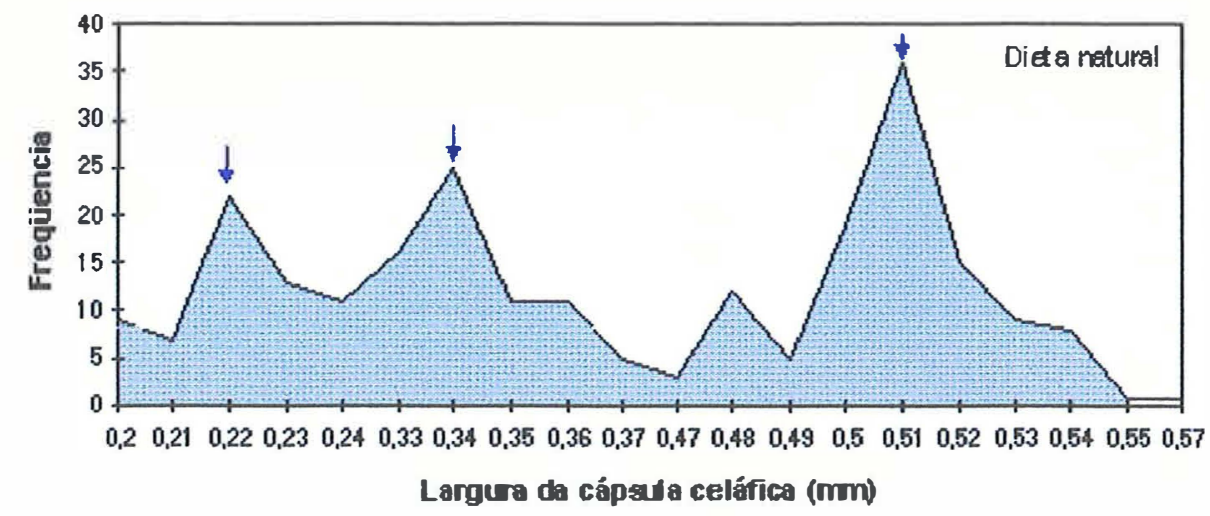

Figura 7. Curva de distribuição de freqüência de larguras de cápsulas cefálicas de larvas de $D$. speciosa criadas em dieta natural. As setas indicam os ínstares.

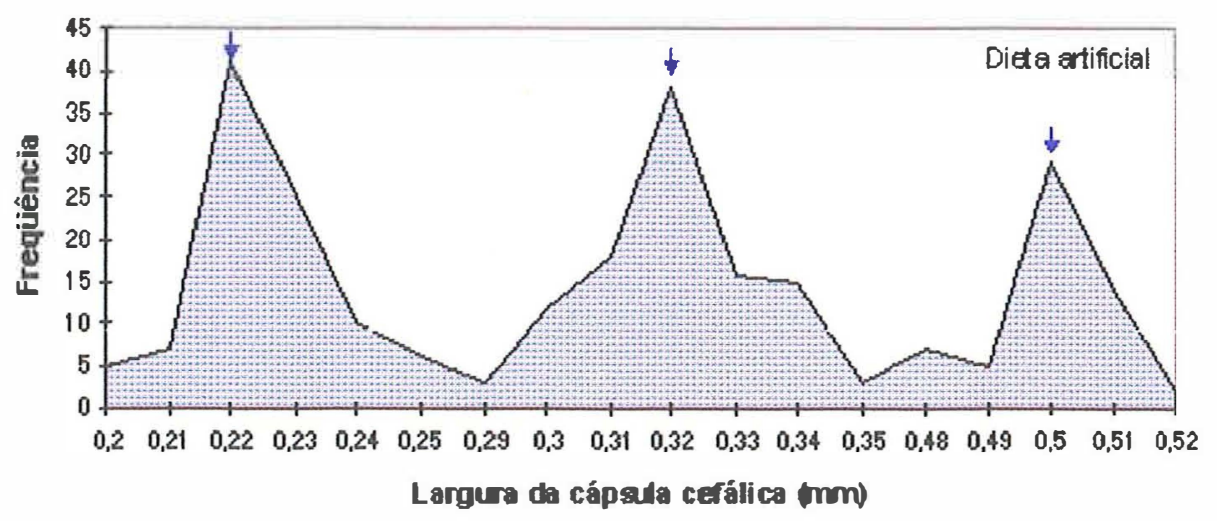

Figura 8. Curva de distribuição de freqüência de largura de cápsulas cefálicas de larvas de $D$. speciosa criadas em dieta artificial. As setas indicam os ínstares. 


\subsubsection{Fase adulta}

4.1.2.1. Períodos de pré-oviposição e oviposição

O períodos médios de pré-oviposição de adultos, provenientes de larvas criadas em dietas natural e artificial, foram 10,9 e 11,5 dias, respectivamente. Estes valores são próximos àqueles obtidos por HAJI (1981) e SILVA-WERNECK et al. (1995). No entanto, os periodos médios de oviposição para dieta natural (40,2 dias) e artificial (36,0 dias) (Tabela 4), diferiram dos períodos de oviposição registrados por HAJI (1981), CARVALHO \& HOHMANN (1982) e SILVA-WERNECK et al. (1995) que foram de 8,$99 ; 5,40 ;$ e 16,60 dias, respectivamente. Embora não tenha sido observado, especificamente, o número e o tempo de duração da cópula de D. speciosa, os dados dos períodos de oviposição, tanto para dieta natural como artificial, estão coerentes com a informação dada por LEW \& BALL (1980), que afirmaram que os espermatóforos inseminados em fêmeas de D. virgifera desapareciam em 7 dias, mas os espermatozóides permaneciam viáveis por um período 40 dias, aproximadamente. 
Tabela 4. Duração média (dias) dos períodos de pré-oviposição e oviposição de $D$. speciosa, criada em dietas natural e artificial, durante a fase larval

\begin{tabular}{ccccc}
\hline Dieta & Pré-oviposição & I.V.* & Oviposição & I.V.* \\
\hline Natural & $10,9 \pm 2,8$ & $7-16$ & $40,2 \pm 12,1$ & $28-60$ \\
Artificial & $11,5 \pm 1,0$ & $10-13$ & $36,0 \pm 16,6$ & $8-45$ \\
\hline * Intervalo de variação & &
\end{tabular}

\subsubsection{Fecundidade}

Em dieta natural, o número médio de posturas por fêmea $(15,1)$ e o número médio de ovos por fêmea (1011), foram maiores do que aqueles observados em dieta artificial, enquanto que os dados de viabilidade dos ovos foram semelhantes (Tabela 5).

O número médio de 1011 ovos por fêmea, obtido em dieta natural, foi expressivamente maior do que os valores: 419,$57 ; 143,7$ e 384,60 ovos por fêmea obtidos por HAJI (1981), CARVALHO \& HOHMANN (1982) e SILVA-WERNECK et al. (1995), respectivamente, os quais, também utilizaram foliolos de feijoeiro para alimentação dos adultos.

As fêmeas de $D$. speciosa costumam ovipositar intercalando os dias de postura e variando bastante o número de ovos/postura. 0 ritmo de postura para dieta natural indicou que as fêmeas realizaram um total de até 21 
posturas, num período médio de 40,2 dias, com picos observados no 3‥ 70 e 10 dias de postura. A mesma tendência do ritmo de postura foi observada com relação à dieta artificial, onde as fêmeas colocaram maior número de ovos nas primeiras posturas (30 e 60 dias) (Figura 9).

Tabela 5. Número médio de posturas por fêmea, número médio de ovos por fêmea e viabilidade dos ovos de D. speciosa, criada em dietas natural e artificial, durante a fase larval

\begin{tabular}{lrrrrr}
\hline Dieta & Posturas/fêmea & I.V.* & Ovos/fêmea & I.V.* & Viabilidade (\%) \\
\hline Natural & $15,1 \pm 4,0$ & $10-21$ & $1011 \pm 533$ & $352-2068$ & $73,7 \pm 15,2$ \\
Artificial & $10,4 \pm 5,1$ & $4-20$ & $433 \pm 300$ & $79-909$ & $74,5 \pm 11,1$ \\
\hline *Intervalo de variação & & & &
\end{tabular}




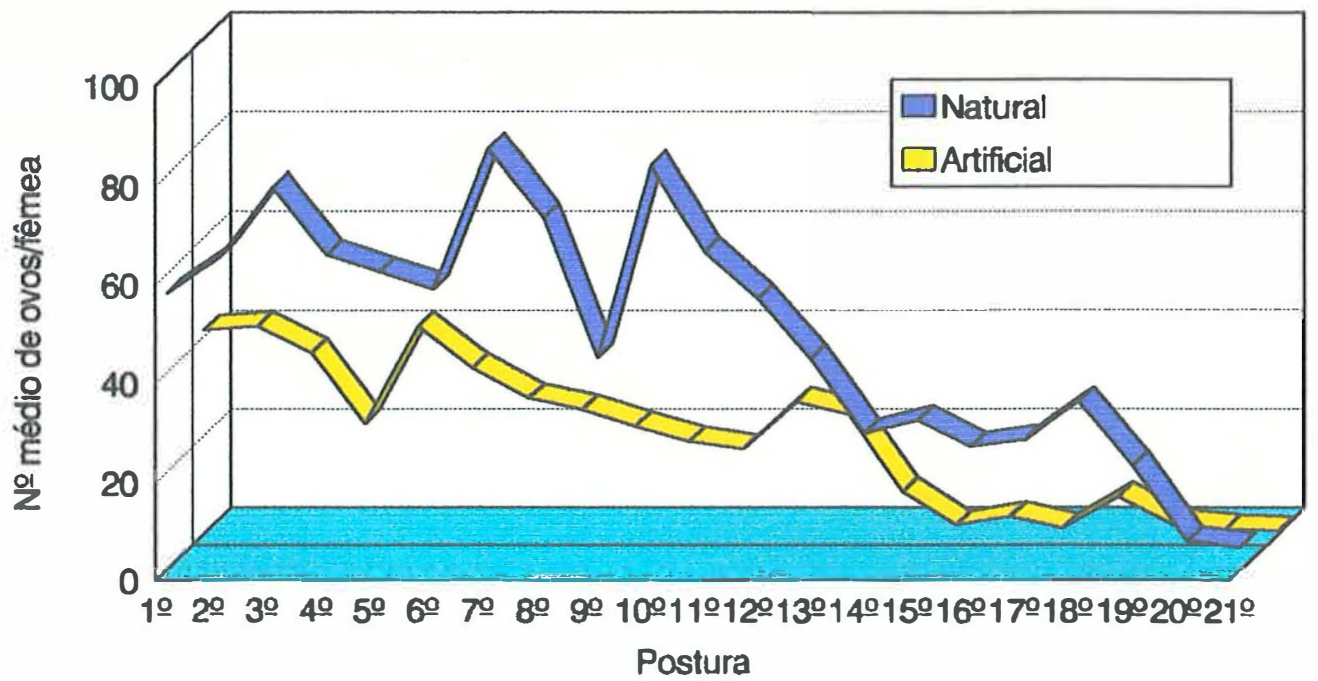

Figura 9. Ritmo de postura de D. speciosa criada em dietas natural e artificial, durante a fase larval.

\subsubsection{Longevidade de adultos}

A longevidade de adultos de $D$. speciosa diferiu em função das dietas e do sexo . Em dieta natural, a longevidade média dos machos $(41,8$ dias) e das fêmeas (51,6 dias) foi menor, quando comparada com a longevidade de 55,5 dias para machos e de 58,5 dias para fêmeas, obtida em dieta artificial (Tabela 6). As curvas de sobrevivência para ambos os sexos obedeceram ao modelo de Weibull. Os valores dos parâmetros de forma (â) maiores do que 1,0 (Figuras 10 e 11) evidenciam que a curva é do tipo 1, isto é, os adultos apresentaram uma taxa de mortalidade que aumentou com o tempo (SGRILLO, 1982). A menor longevidade observada para fêmeas, em dieta natural, pode ser explicada pelo fato de terem 
dispendido uma quantidade maior de energia, ao ovipositarem o dobro em relação às fêmeas criadas em dieta artificial, embora não haja explicação para a maior longevidade dos machos neste meio. 0 resultado de longevidade média de fêmeas, em dieta natural, ficou próximo ao obtido por HAJl (1981), mas discrepante em relação aos valores encontrados por CARVALHO \& HOHMANN (1982) e SILVA-WERNECK et al. (1995). As diferenças encontradas, podem ser atribuídas aos diferentes métodos empregados nà criação dos adultos e aos diferentes "strains" e condições de laboratório utilizados.

Não foram observadas differenças morfológicas entre os adultos criados em dieta natural e artificial; no entanto, o manuseio excessivo e a exposição, principalmente da fase de pupa à luz, provocaram o aparecimento de adultos com as cores verde e amarela não muito bem fixadas, em ambas dietas, fenômeno também observado em populações de campo. Entretanto, tal freqüência foi maior em insetos criados em dieta artificial, talvez pelo fato da maior manipulacão neste meio. Salienta-se ainda, que a viabilidade observada em dieta artificial, para o período larvaadulto, foi baixa $(38,7 \%)$. Esta viabilidade poderá ser melhorada com a adaptação da criação às condições de laboratório. 
Tabela 6. Longevidade média de machos, fêmeas e de machos + fêmeas de D. speciosa, criada em dietas natural e artificial, durante a fase larval.

longevidade (dias)

Dieta machos $\quad$ I. $V^{\star}$ fêmeas $\quad$ I. $V^{\star}$ machos + fêmeas

\begin{tabular}{llllll} 
Natural & 41,8 & $52-69$ & 51,6 & $43-73$ & 46,0 \\
Artificial & 55,5 & $28-72$ & 58,5 & $17-82$ & 56,3 \\
\hline
\end{tabular}

*Intervalo de variação

4.1.2.4. Periodicidade de postura.

Foi observado que, em condições de laboratório (fotofase de 14 ), as fêmeas de $D$. speciosa costumavam ovipositar na presença de luz, concentrando sua postura no periodo das 14 às 18 horas (Figura. 12). Neste intervalo de tempo, deve-se evitar a troca de alimentos e o manuseio da gaiola de adultos, para não perturbar o ambiente e prejudicar a postura. 

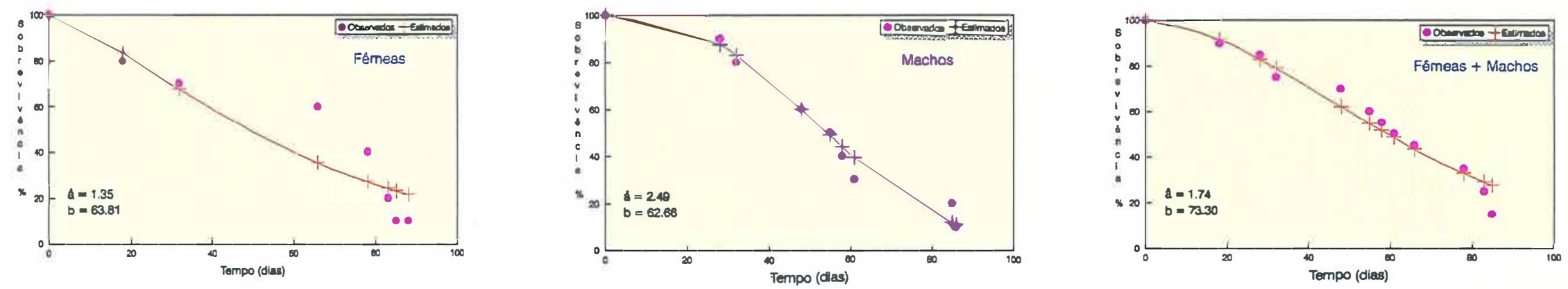

Figura 10. Sobrevivência de fêmeas, machos e fêmeas + machos de $D$. speciosa cujas larvas foram criadas em dieta artificial. Valores observados e estimados pela equação de Weibull em temperatura de $25 \pm 2^{\circ} \mathrm{C}$; UR: $60 \pm 10 \%$ e fotofase: $14 \mathrm{~h}$.
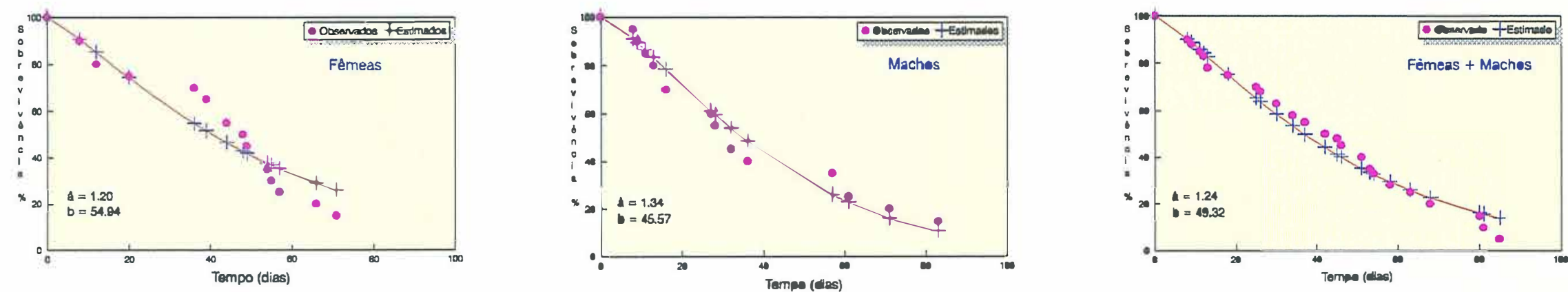

Figura 11. Sobrevivência de fêmeas, machos e fêmeas + machos de $D$. speciosa cujas larvas foram criadas em dieta natural. Valores observados e estimados pela equação de Weibull em temperatura de $25 \pm 2^{\circ} \mathrm{C}$; UR: $60 \pm 10 \%$ e fotofase: $14 \mathrm{~h}$. 


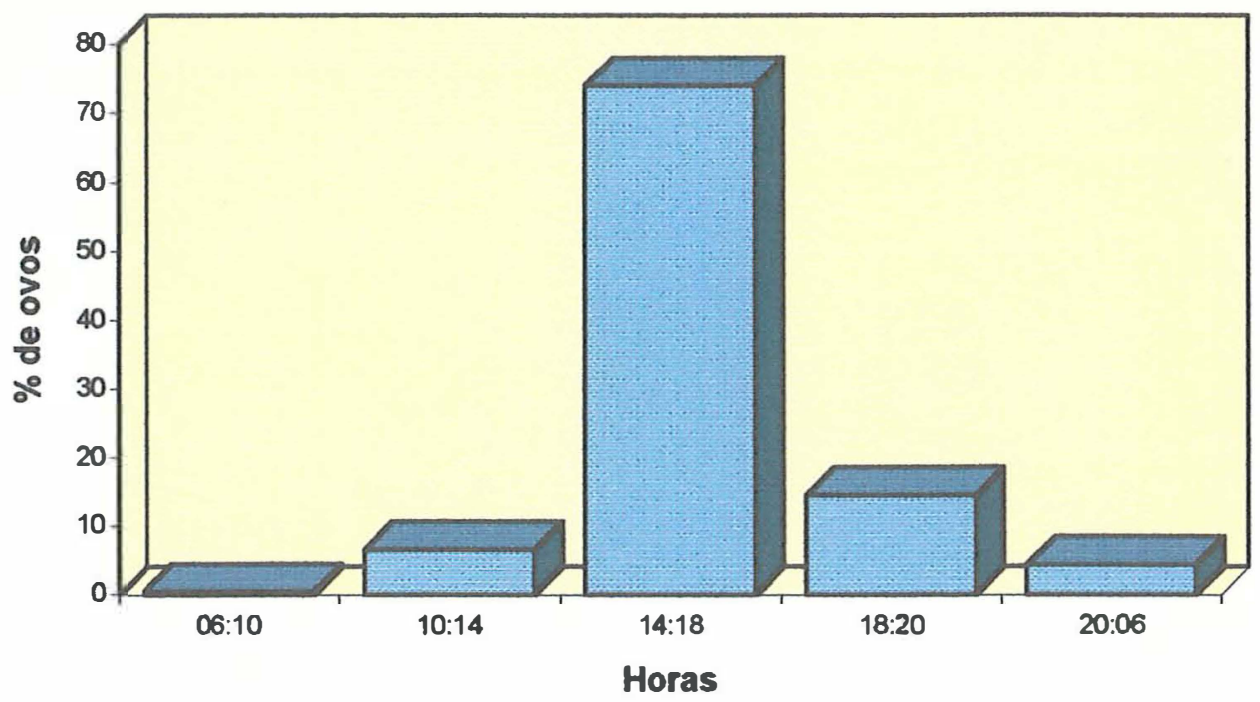

Figura 12. Periodicidade diária de postura de $D$. speciosa, proveniente de dieta natural, em condições de laboratório. Temperatura $25 \pm 2^{\circ} \mathrm{C}$; UR $60 \pm 10 \%$; Fotofase: $14 h$.

4.1.3. Influência do fotoperíodo no período de incubação e na viabilidade dos ovos de D. speciosa

O fotoperiodo de 14 horas de luz (fotofase) e 10 horas de escuro (escotofase) ajustado para o trabalho rotineiro do Laboratório de Biologia de Insetos da ESALQ/USP, não influenciou o período de incubação e a viabilidade dos ovos de D. speciosa, quando comparado, com o tratamento de 24 horas de escuro (Tabela 7). Desta forma, não há necessidade de se tomarem maiores cuidados com relação ao fotoperíodo na manipulação dos ovos em criações de laboratório desta espécie. 
Embora não exista nenhuma relação entre a luminosidade natural e a de laboratório, em termos de intensidade e qualidade, era de se esperar tal resultado, desde que $D$. speciosa realiza postura no solo, em diferentes profundidades (WEISS et al. 1983), local em que a luz, aparentemente, exerce pouca influência sobre esta fase do inseto.

Tabela 7. Influência do fotoperíodo no período de incubação e na viabilidade de ovos de D. speciosa. Temperatura $25 \pm 2^{\circ}$ C; UR 60 $\pm 10 \%$; Fotofase $14 \mathrm{~h}$.

\begin{tabular}{cccc}
\hline \multicolumn{2}{c}{ Fotoperíodo } & Duração & Viabilidade \\
Luz & Escuro & (dias) & (\%) \\
\hline $14:$ & 10 & $8,3 \pm 0,5$ a & $94,0 \pm 2,1$ a \\
$0:$ & 24 & $8,7 \pm 0,6$ a & $86,0 \pm 3,3$ a \\
\hline Médias seguidas da mesma letra, na coluna, não diferem entre si,pelo teste \\
de Tukey, ao nível de 5\% de probabilidade.
\end{tabular}

4.2. Influência de diferentes cores de gaze na oviposição de $D$. speciosa

Devido à dificuldade de separar os ovos do solo, utilizou-se gaze como substrato de postura. Inicialmente, foi realizado um teste para se estudar a preferência das fêmeas pelas diferentes cores do substrato. 
As cores preta e verde foram as preferidas para oviposição (Tabela 8). As cores amarela e branca exerceram pouca atratividade para a postura, embora tenham sido referidas como eficientes quando utilizadas, em armadilha adesiva, na captura de adultos de D. speciosa por LARA et al. (1976). A cor amarela também foi destacada como eficiente na atratividade e captura de adultos das espécies $D$. barberi e $D$. virgifera por STEFFEY et al. (1982) e LADD Jr et al. (1984).

Tabela 8. Número médio de ovos colocados por $D$. speciosa em substrato (gaze) de diferentes cores. Temperatura $25 \pm 2^{\circ} \mathrm{C}$; UR $60 \pm$ 10\%; Fotofase: $14 \mathrm{~h}$.

\begin{tabular}{lr}
\hline Cor & Número médio de ovos* $^{*}$ \\
\hline Preta & $310,8 \pm 80,8 \mathrm{a}$ \\
Verde & $294,9 \pm 37,2 \mathrm{a}$ \\
Vermelha & $68,5 \pm 1,5 \mathrm{~b}$ \\
Amarela & $7,5 \pm 0,9 \mathrm{C}$ \\
Branca & $6,3 \pm 0,5 \mathrm{C}$ \\
\hline Médias seguidas pela mesma letra, não diferem entre si pelo teste deTukey, \\
ao nivel de 5\% de probabilidade. \\
* Dados originais transformados em $\sqrt{x+0,5}$ & para efeito de análise \\
estatística &
\end{tabular}


4.3. Efeito da temperatura e determinação das exigências térmicas no ciclo biológico de D. speciosa.

\subsubsection{Fase de ovo}

O período de incubação diminuiu conforme a temperatura aumentou de 18 para $32^{\circ} \mathrm{C}$ (Tabela 9). As diferenças foram mais evidentes quando as temperaturas foram mais espaçadas $\left(18,22\right.$ e $\left.32^{\circ} \mathrm{C}\right)$. Em temperaturas mais próximas $\left(20\right.$ e $22^{\circ} \mathrm{C} ; 30$ e $\left.32^{\circ} \mathrm{C}\right)$ as diferenças não foram significativas. $O$ período de incubação de $\mathbf{8 , 8 0}$ dias, na temperatura de $25^{\circ} \mathrm{C}$, foi próximo daquele obtido por SILVA-WERNECK et al. (1995) à temperatura de $26 \pm 2^{\circ} \mathrm{C}(8,1)$ e superior ao obtido por CARVALHO \& HOHMANN (1982), que foi de 6,4 dias em temperatura próxima de $25^{\circ} \mathrm{C}$.

A viabilidade dos ovos, tratados com solução de hipoclorito de sódio $(0,05 \%)$ por 2 minutos, foi menor nas temperaturas extremas $\left(18\right.$ e $\left.32^{\circ} \mathrm{C}\right)$, embora sem diferir estatisticamente das demais, sendo que na temperatura de $18^{\circ} \mathrm{C}$, o longo período de desenvolvimento embrionário (Tabela 9), proporcionou o aparecimento de agentes patogênicos, principalmente fungos. $\mathrm{Na}$ faixa de temperatura de $20-25^{\circ} \mathrm{C}$ a viabilidade foi superior aos valores obtidos por CARVALHO \& HOHMANN (1982); SILVA-WERNECK et al. (1995) e por HAJI (1981). Esta última autora, obteve uma viabilidade muito baixa para ovos de $D$. speciosa $(29 \%)$ em temperatura ambiente, 
provavelmente devido à baixa concentração de hipoclorito de sódio $(0,005 \%)$, utilizada no tratamento dos ovos, o que pode ter permitido o desenvolvimento de patógenos.

Tabela 9. Período médio de incubação e viabilidade de ovos de $D$. speciosa, sob diferentes temperaturas. UR $60 \pm 10 \%$; Fotofase: $14 \mathrm{~h}$.

\begin{tabular}{cccc}
\hline $\begin{array}{c}\text { Temperatura } \\
\left({ }^{\circ} \mathrm{C}\right)\end{array}$ & $\begin{array}{c}\text { Duração* }^{*} \\
\text { (dias) }\end{array}$ & $\begin{array}{l}\text { I.V } \\
\text { (dias) }\end{array}$ & $\begin{array}{c}\text { Viabilidade } \\
\text { (\%) }\end{array}$ \\
\hline 18 & $19,6 \pm 0,2 \mathrm{a}$ & ${ }^{*} / 19-23^{7}$ & $68,0 \pm 5,5 \mathrm{a}$ \\
20 & $11,8 \pm 0,1 \mathrm{~b}$ & $11-13$ & $80,0 \pm 5,1 \mathrm{a}$ \\
22 & $11,3 \pm 0,1 \mathrm{~b}$ & $10-13$ & $72,0 \pm 3,9 \mathrm{a}$ \\
25 & $8,8 \pm 0,4 \mathrm{c}$ & $7-10$ & $82,0 \pm 4,7 \mathrm{a}$ \\
30 & $6,3 \pm 0,2 \mathrm{~d}$ & $6-8$ & $67,0 \pm 6,0 \mathrm{a}$ \\
32 & $5,7 \pm 0,3 \mathrm{~d}$ & $5-7$ & $67,0 \pm 4,1 \mathrm{a}$ \\
\hline
\end{tabular}

* Ovos provenientes de insetos criados em dieta natural.

**. Intervalo de variação.

Médias seguidas da mesma letra, na mesma coluna, não diferem entre si, pelo teste deTukey, ao nível de $5 \%$ de probabilidade. 


\section{3.2. Período larva-adulto}

O período de desenvolvimento larva-adulto, na faixa de 18 a $32^{\circ} \mathrm{C}$, esteve inversamente relacionada com o aumento da temperatura. As viabilidades para as temperaturas extremas $\left(18\right.$ e $\left.32^{\circ} \mathrm{C}\right)$ foram baixas, mas satisfatórias na faixa de 20 a $30^{\circ} \mathrm{C}$, considerando-se, como referência, criação de crisomelídeos, em laboratório (Tabela 10). Os resultados estão coerentes com os de JACKSON \& ELLIOTT (1988) que consideraram a faixa de 21 a $30^{\circ} \mathrm{C}$, ótima para o desenvolvimento larval da espécie $D$. $v$. virgifera. A velocidade de desenvolvimento, em função da temperatura, ajustou-se ao modelo linear obtido através da recíproca da equação da hipérbole (HADDAD \& PARRA, 1984). Os valores dos limites térmicos inferiores de desenvolvimento das fases de ovo, período larva-adulto e ciclo total (ovo-adulto) foram próximos (Tabela 11; Figura 13).

O limite térmico inferior (Tb) de desenvolvimento embrionário foi de $11,1^{\circ} \mathrm{C}$, valor muito próximo dos valores 11,$11 ; 11,10$ e $10,50 \mathrm{C}^{\circ}$ obtidos para ovos de $D$. longicornis e D. virgifera e D. v. virgifera, respectivamente, por CHIANG \& SISSON (1968), WILDE (1971) e SCHAAFSMA et al. (1991), e diferindo do valor $12,7^{\circ} \mathrm{C}$ obtido para ovos de D. v. virgifera por LEVINE et al. (1992). No entanto, o valor da constante térmica (119,1 GD) obtido para ovos de $D$. speciosa, foi muito inferior aos 500 graus-dia obtidos para ovos de D. longicornis (CHIANG \& SISSON, 
1968), aos 210 graus-dia obtido para ovos de D. v. virgifera (LEVINE et al. 1992) e əos 258 graus-dia obtidos para ovos de D. v. virgifera (SCHAAFSMA et al. 1991). Estas diferenças existem, provavelmente, devido ao fato das espécies referidas ocorrerem em condições climáticas diferentes e ainda por serem, muitas delas, univoltinas e apresentarem diapausa nas fase de ovo.

Tabela 10. Período médio de desenvolvimento e viabilidade do período larva-adulto de $D$. speciosa em dieta natural, sob diferentes temperaturas. UR $60 \pm 10 \%$; Fotofase: $14 \mathrm{~h}$.

\begin{tabular}{cccc}
\hline $\begin{array}{c}\text { Temperatura } \\
\left({ }^{\circ} \mathrm{C}\right)\end{array}$ & $\begin{array}{c}\text { Duração } \\
\text { (dias) }\end{array}$ & $\begin{array}{c}\text { I.V* } \\
\text { (dias) }\end{array}$ & $\begin{array}{c}\text { Viabilidade } \\
(\%)\end{array}$ \\
\hline 18 & $49,6 \pm 0,9$ a & $45-54$ & $28,0 \pm 4,4 \mathrm{C}$ \\
20 & $37,8 \pm 1,2 \mathrm{~b}$ & $35-50$ & $53,0 \pm 8,5 \mathrm{a}$ \\
22 & $33,6 \pm 0,9 \mathrm{c}$ & $29-42$ & $51,2 \pm 3,7 \mathrm{ab}$ \\
25 & $25,2 \pm 0,8 \mathrm{~d}$ & $22-31$ & $48,4 \pm 6,1 \mathrm{~b}$ \\
30 & $20,2 \pm 0,8 \mathrm{e}$ & $22-25$ & $59,2 \pm 4,9$ a \\
32 & $16,80 \pm 1,3 \mathrm{f}$ & $14-21$ & $28,0 \pm 3,6 \mathrm{c}$ \\
\hline Médias seguidas da mesma letra, na coluna,não diferem entre si pelo teste \\
deTukey, ao nível de 5\% de probabilidade. & & \\
* Intervalo de variação &
\end{tabular}


Tabela 11. Temperaturas base (Tb), constantes térmica (K), equações da velocidade de desenvolvimento (1/D) e coeficientes de determinação $\left(R^{2}\right)$ das diferentes fases do ciclo biológico de $D$. speciosa, criada em dieta natural.

\begin{tabular}{ccccc}
\hline Fase/Período & Tb $\left({ }^{\circ} \mathrm{C}\right)$ & $K(G D)$ & Equação (1/D) & $R^{2}(\%)$ \\
\hline Ovo & 11,1 & 119,1 & $-0,093346+0,008395 \times$ & 98,2 \\
Larva - adulto & 10,9 & 355,9 & $-0,030585+0,002810 \times$ & 97,9 \\
Ovo- adulto & 11,4 & 474,9 & $-0,023243+0,002105 \times$ & 99,1 \\
\hline $\begin{array}{l}\text { De Desenvolvimento (dias) } \\
X=\text { Temperatura ( }\end{array}$ & & & \\
7
\end{tabular}

O estudo da influência da temperatura e das exigências térmicas, nas diferentes fases de desenvolvimento de $D$. speciosa, poderá ser de grande valia para futuros estudos de modelos de simulação e de zoneamento ecológico da praga, onde a temperatura entra como um dos fatores importantes para se determinar a ocorrência e a distribuição de suas populações, nas diferentes regiões produtoras de milho e de outras culturas hospedeiras da praga. 

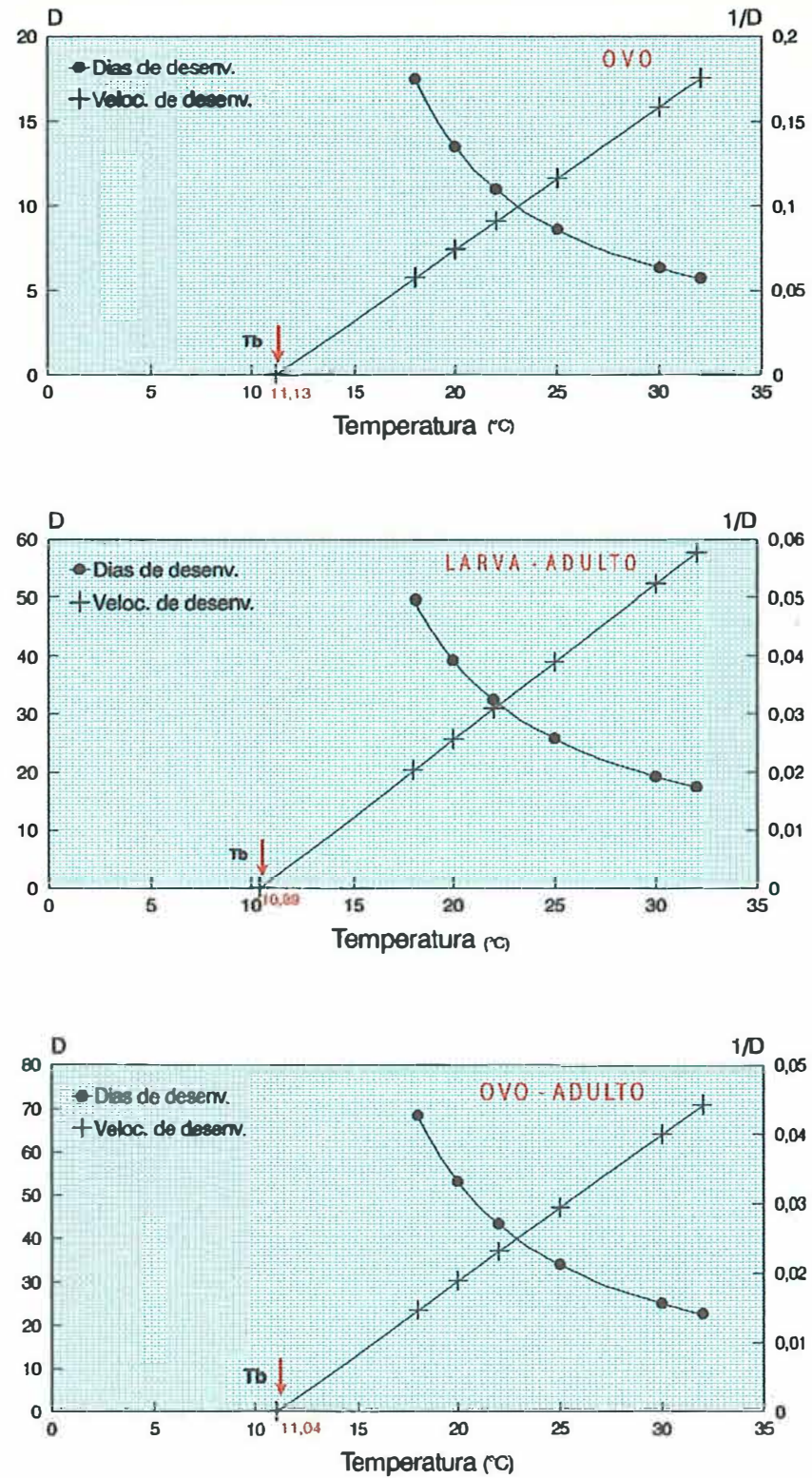

Figura13. Relação entre temperatura, tempo e a velocidade desenvolvimento da fase de ovo, período larva-adulto e do ciclo biológico (ovo-adulto) de D. speciosa. 
4.4. Influência de fatores abióticos e bióticos na oviposição de $D$. speciosa

\subsubsection{Influência do tipo e da umidade do solo na oviposição}

Dentre os fatores ecológicos que influenciam a oviposição de crisomelídeos, de modo geral, estão as propriedades físico-químicas do solo. Nesta pesquisa, ficou demonstrada a preferência de $D$. speciosa em ovipositar em solos mais escuros, com maiores teores de matéria orgânica (Tabela 12), quando os diferentes tratamentos foram submetidos à mesma condição de umidade, ou seja, saturação. Os resultados apresentados estão coerentes com aqueles relatados por Deitz ${ }^{4}$ (1976), citado por MARRONE \& STINNER (1983a) e BRUST \& HOUSE (1990a), que também observaram preferência de oviposição, de diferentes espécies de crisomelídeos, por solos com maiores teores de matéria orgânica. Embora a influência de fatores químicos do solo sobre a biologia e o comportamento dos crisomelídeios seja pouco estudada, verificou-se que a postura de $D$. speciosa foi maior em solos com maiores teores de potássio (Apêndice 2). Esta observação está coerente com a de TURPIN et al. (1972), que

\footnotetext{
${ }^{4}$ DEITZ, L.L.; VAN DUYN, J.W.; BRADLLEY JR, J. R.; RABB, R. L.; BROOKS, W. M.; STINNER, R.E. A guide to the identification and biology o soybean arthropods in North Carolina. Releigh, North Caroline Experimental Estation, 1976.26p. (Techinical Bulletin, 238).
} 
verificaram uma correlação positiva entre os danos causados em milho por Diabrotica spp. e os teores de potássio, em diferentes áreas cultivadas.

A umidade do solo é um dos fatores abióticos importantes na preferência de oviposição dos crisomelídeos (Galerucinae), sendo mesmo determinante no comportamento das fêmeas que ovipositam em fissuras ou rachaduras do solo, procurando uma condição melhor de umidade (GEORGE \& ORTMAN, 1965; CHALFANT \& MITCHEL, 1967; KIRK et al, 1968; WEISS et al., 1983). Também ficou evidenciado que a espécie $D$. speciosa teve nítida preferência em ovipositar em solos com teores de umidade acima de $26 \%$, evitando colocar seus ovos em solos mais secos (Tabela 13). Tal fato está relacionado à necessidade dos ovos absorverem água para assegurar o desenvolvimento embrionário, conforme foi verificado em ovos do crisomelídeo Cerotoma trifurcata (MARRONE \& STINNER, 1983b). Em ovos da espécie Phyllophaga cuyabana (Coleoptera: Scarabaeidae), considerada praga subterrânea da cultura da soja, foi observado aumento de peso e de tamanho, durante os primeiros dias de incubação, devido a absorção de água (SANTOS, 1992). É interessante salientar que a espécie $D$. speciosa está se evidenciando como praga em áreas de produção de milho irrigado, onde as condições de umidade favorecem o desenvolvimento do inseto. 
Tabela 12. Número médio de ovos colocados por D. speciosa, em diferentes tipos de solo, em condições de livre escolha. Temperatura: $25 \pm 2^{\circ} \mathrm{C}$; UR: $60 \pm 10 \%$; fotofase: $14 \mathrm{~h}$.

\begin{tabular}{lc}
\hline \multicolumn{1}{c}{ Solos } & № médio de ovos* \\
\hline Terra Roxa Estruturada Distrófica & $468,8 \pm 54,7$ a \\
Latossolo Roxo Distrófico & $81,0 \pm 13,1 \mathrm{~b}$ \\
Cambissolo Húmico Álico & $51,0 \pm 12,3 \mathrm{~b} \mathrm{c}$ \\
Terra & $33,6 \pm 9, \mathrm{c}$ \\
Roxa Estruturada Latossólica & \\
\hline
\end{tabular}

Médias seguidas pela mesma letra não diferem entre si, pelo teste de Tukey, ao nivel de $5 \%$ de probabilidade.

* Dados originais transformados em $\sqrt{x}$ para efeito de análise estatística 
Tabela 13. Número médio de ovos colocados por D. speciosa, em solo (Terra Roxa Estruturada Distrófica) com diferentes teores de umidade, em teste de livre escolha. Temperatura: $25 \pm 2^{\circ} \mathrm{C}$ UR $60 \pm 10 \%$; fotofase: $14 \mathrm{~h}$.

\begin{tabular}{cc}
\hline Umidade (\%) & No médio de ovos* \\
\hline 63 & $320,8 \pm 62,3 \mathrm{a}$ \\
32 & $210,0 \pm 62,5 \mathrm{a}$ \\
29 & $302,4 \pm 54,3 \mathrm{a}$ \\
26 & $174,8 \pm 45,8 \mathrm{ab}$ \\
24 & $100,8 \pm 48,78 \mathrm{~b}$ \\
22 & $17,8 \pm 3,9 \mathrm{c}$ \\
\hline Médias seguidas da mesma letra, não diferem entre si pelo teste de Tukey, \\
ao nivel de 5\% de probabilidade. \\
* Dados originais transformados em log x para efeito de análise estatistica.
\end{tabular}

4.4.2. Influência de plantas hospedeiras na oviposição

Embora os crisomelídeos da sub família Galerucinae ovipositem no solo, as plantas hospedeiras parecem ter papel importante na orientação das fêmeas, conforme ficou demonstrado em teste de livre escolha para a oviposição de $D$. speciosa, onde o número médio de ovos, colocados junto às plântulas de milho, foi mais alto (Tabela 14). 
Comportamento idêntico foi observado com outras espécies de crisomelídeos, relatado por KIRK et al. (1968), BRUST \& HOUSE (1990b) e BOETEL et al. (1992), no qual as gramíneas, principalmente, exerceram influência na oviposição. É interessante notar, que o milho não é a planta hospedeira favorita para a alimentaçào dos adultos de Diabrotica, mas é a mais apropriada para o desenvolvimento das larvas, conforme ficou demonstrado no trabalho de BRANSON \& ORTMAN (1970) com a espécie $D$. virgifera. Em contraposição, JOHNSON \& TURPIN (1985) afirmaram que a gramínea rabo de raposa (Setaria spp.), não exerceu nenhuma influência na oviposição de algumas espécies de Diabrotica, entendendo que a interação de fatores abióticos do solo, como a textura e a umidade, são mais importantes que a planta hospedeira na preferência por oviposição.

A alimentação diferenciada observada para a fase larval e a fase adulta dos crisomelídeos pode determinar estratégias importantes de controle da praga dentro do enfoque de sua ecologia nutricional, já que os processos ecológicos fisiológicos e comportamentais dos insetos são conseqüências do seu hábito alimentar. Segundo Geier ${ }^{5}$ (1966) , citado por PANIZZI \& PARRA (1991), uma das maneiras de manejar populações de insetos-pragas, seria pela modificação intrínseca dos habitats favoráveis, tornando-os inadequados para as pragas em questão. Conforme ficou evidenciado nesta pesquisa, o milho foi a planta hospedeira mais favorável para a oviposição de D. speciosa, certamente para assegurar o

\footnotetext{
${ }^{5}$ GEIER, P.W. Management of insect pests. Ann. Rev. Entomol. 111:471-490, 1966.
} 
desenvolvimento da fase larval, embora tivessem sido encontrados ovos, em menor número, junto às plântulas de feijão e soja que servem de alimentação para os adultos, mas certamente não são plantas hospedeiras apropriadas para o desenvolvimento das larvas. Esta observação está coerente com aquela feita por BRUST \& HOUSE (1990b) na qual a espécie D. u. howardi preferia ovipositar junto à gramíneas, em vasos onde os adultos tinham, como fonte de alimentação, ervas daninhas de folhas largas (leguminosas), quando comparado com vasos onde se ofereciam como fonte de alimentação, ervas daninhas de folhas estreitas (gramíneas) ou apenas solo nu, sem nenhuma fonte alimentar. Ainda sob o ponto de vista da ecologia nutricional, é importante salientar o trabalho de CINERESKI \& CHIANG (1968) que concluíram, através de análises do conteúdo estomacal, que fêmeas de $D$. barberi, após se alimentarem em outras plantas hospedeiras, retornavam às areas cultivadas com milho para ovipositarem. Neste sentido, seria interessante aprofundar as pesquisas para se conhecer melhor o regime alimentar de adultos e larvas de $D$. speciosa com o objetivo de dificultar sua colonização e minimizar seus danos, realizando o manejo de culturas. 
Tabela 14. Número médio de ovos colocados por $D$. speciosa em diferentes plantas hospedeiras e no solo nu (Terra Roxa Estruturada Distrófica), em teste de livre escolha. Temperatura; $25 \pm 2^{\circ} \mathrm{C}$; UR; $60 \pm 10 \%$; Fotofase: $14 \mathrm{~h}$.

\begin{tabular}{lc}
\hline Tratamento & № médio de ovos* \\
\hline Milho (pipoca) & $87,8 \pm 20,2 \mathrm{a}$ \\
Feijão ("Carioca-80") & $30,0 \pm 7,0 \mathrm{ab}$ \\
Soja ("BR-37”) & $24,6 \pm 8,8 \mathrm{ab}$ \\
Arroz ("IAC-165") & $24,0 \pm 6,8 \mathrm{~b}$ \\
Solo & $10,2 \pm 1,5 \mathrm{~b}$ \\
\hline
\end{tabular}

Médias seguidas pela mesma letra não diferem entre si, pelo teste de Tukey, ao nivel de $5 \%$ de probabilidade.

* Dados originais transformados em $\log$ de $x$ para efeito de análise estatística

Estudos mais aprofundados das interações dos estágios imaturos da praga com as propriedades físico-químicas do solo como: temperatura, umidade, textura, $\mathrm{pH}$, densidade, porosidade, etc., aliados aos estudos básicos que determinam o comportamento dos adultos em relação à sua migração e oviposição, contemplando também os fatores 
abióticos do solo e os fatores bióticos (aleloquímicos) das plantas hospedeiras, podem oferecer subsídios importantes para um melhor entendimento da bioecologia do inseto e proporcionar condições adequadas de manejo e controle.

4.5. Atração de adultos de $D$. speciosa à luzes de diferentes comprimentos de onda.

O número médio de adultos (fêmeas, machos e fêmeas + machos) atraídos por lâmpadas de diferentes cores foi significativamente maior para as luzes BLB e BL, que emitem luz na região de comprimento de ondas mais curtas, ou seja, na região do ultra-violeta, considerada mais eficiente na atração de insetos, de modo geral (Tabela 15). À exceção da luz azul, as demais luzes testadas não foram eficientes na captura do inseto (Figura 14). Os resultados obtidos mostram a especificidade de atração no gênero, desde que BALL (1982), para a espécie $D$. virgifera, observou que as cores amarela e vermelha, consideradas de comprimentos de onda mais longa, foram as mais atrativas aos adultos. 
Tabela 15. Número médio de fêmeas, machos e fêmeas + machos de $D$. speciosa, atraídos por luzes de diferentes comprimentos de onda.

\begin{tabular}{|c|c|c|c|}
\hline \multirow[b]{2}{*}{ Luz } & \multirow[b]{2}{*}{ fêmeas } & \multicolumn{2}{|c|}{ Número de indivíduos atraídos } \\
\hline & & machos* & fêmeas + machos \\
\hline BLB (ultra-violeta) & $13,7 \mathrm{a}$ & $16,5 \mathrm{a}$ & 16,2 a \\
\hline BL (ultra-violeta) & $9,0 \mathrm{a}$ & $7,0 \mathrm{~b}$ & $16,0 \mathrm{a}$ \\
\hline B (azul) & $8,2 a b$ & $6,0 \mathrm{~b}$ & $9,5 a b$ \\
\hline G (verde) & $2,7 \mathrm{bc}$ & $3,0 \mathrm{bc}$ & $4,5 \mathrm{~b}$ \\
\hline CG (verde fria) & $2,6 \mathrm{bc}$ & $2,3 \mathrm{bc}$ & $5,2 \mathrm{~b}$ \\
\hline W (branca quente) & $2,0 \mathrm{C}$ & $1,2 \mathrm{c}$ & $3,7 \mathrm{~b}$ \\
\hline $\begin{array}{l}\text { Médias seguidas pe } \\
\text { teste deTukey, ao ni }\end{array}$ & $\begin{array}{l}\text { mesma let } \\
\text { el de } 5 \% \text { de }\end{array}$ & $\begin{array}{l}\text { as colunas, } \\
\text { abilidade. }\end{array}$ & erem entre si, pelo \\
\hline
\end{tabular}




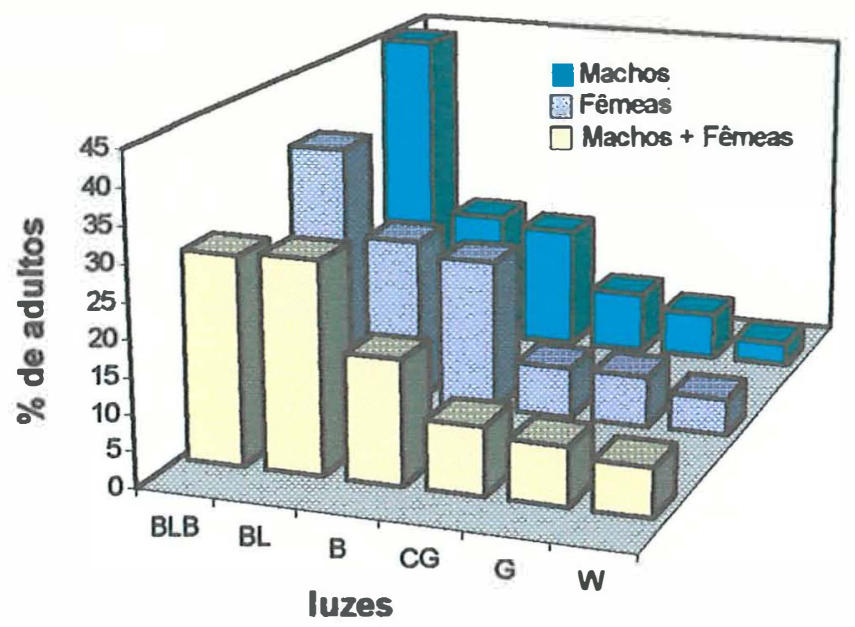

Figura 14. Percentagem de machos, fêmeas e machos + fêmeas de D. speciosa atraídos por luzes de diferentes comprimentos de onda.

4.6. Sistema de criação de $D$. speciosa em laboratório

No decorrer do estudo da biologia de D. speciosa, foi desenvolvida uma técnica de criação do inseto, em dieta natural, nas condições do laboratório (Figura 15). Inicialmente, as larvas recémeclodidas, provenientes de caixas de Petri (local de incubação), eram transferidas para bandejas (Figura1A), forradas com papel germiteste mantido úmido, que continham milho germinado com desenvolvimento de raizes seminais de 3 a 4 dias. As sementes de milho eram inicialmente tratadas com fungicidas e deixadas em água por $\mathbf{2 4}$ horas para apressar o 
processo germinativo. Após 10 a 12 dias, quando as larvas já estavam no ínicio do 3o ínstar, realizava-se o peneiramento das mesmas e, em seguida, eram transferidas para bandejas (Figura 1C) que continham milho germinado e uma mistura (1:1) de solo e areia fina. Após completarem o 3o ínstar (5 a 7 dias), as larvas passavam para o solo, através de orificios da divisória que separa as duas metades da bandeja, onde transformam-se em pré-pupa e pupa. Após 6 a 8 dias, começavam a emergir os adultos, completando-se o ciclo. Normalmente, os adultos, na gaiola de oviposição, eram alimentados com folhas de leguminosas (feijão e soja), cucurbitáceas (folhas de chuchu e polpas de melão e melancia), além de inflorescência feminina de milho que, aparentemente, assegurava uma boa fecundidade. 


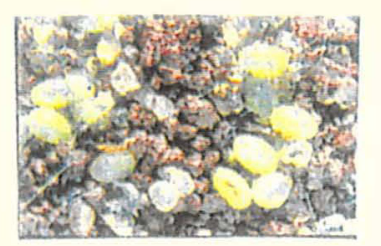

Ovos

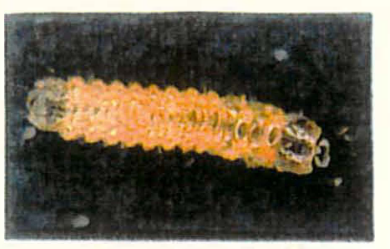

Larvas de $1^{\circ}$ instar $\rightarrow$

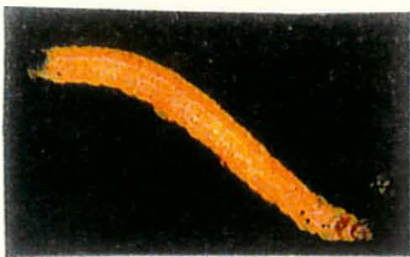

Larvas de $3^{\circ}$ instar $\longrightarrow$

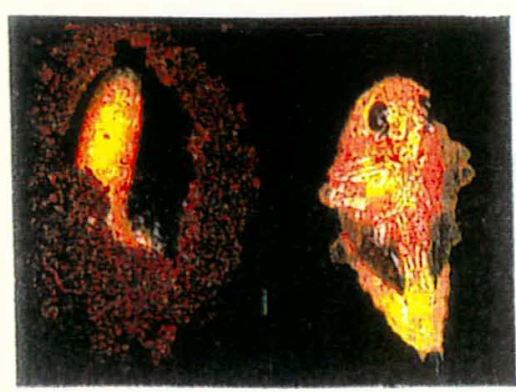

Pré-pupa e pupa

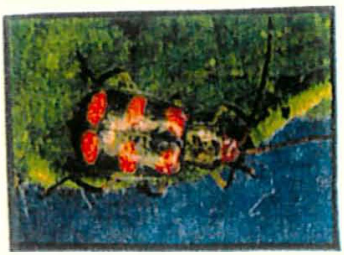

\section{Milho Germinado}

\{3 a 4 (aias\}
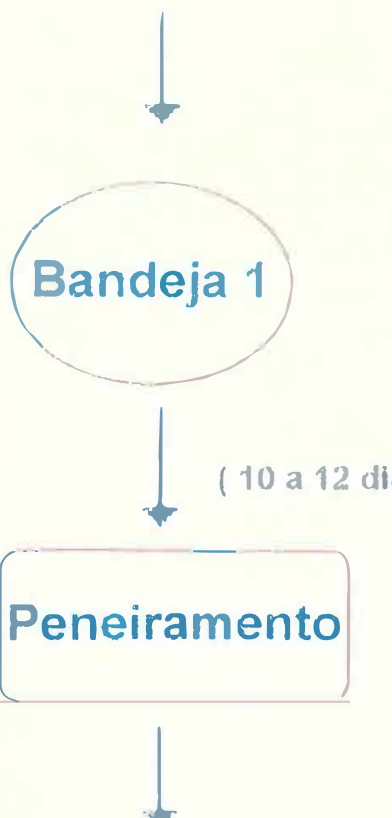

Bandeja 2 ) ( 5 a 7 dias ) (milho e solo)
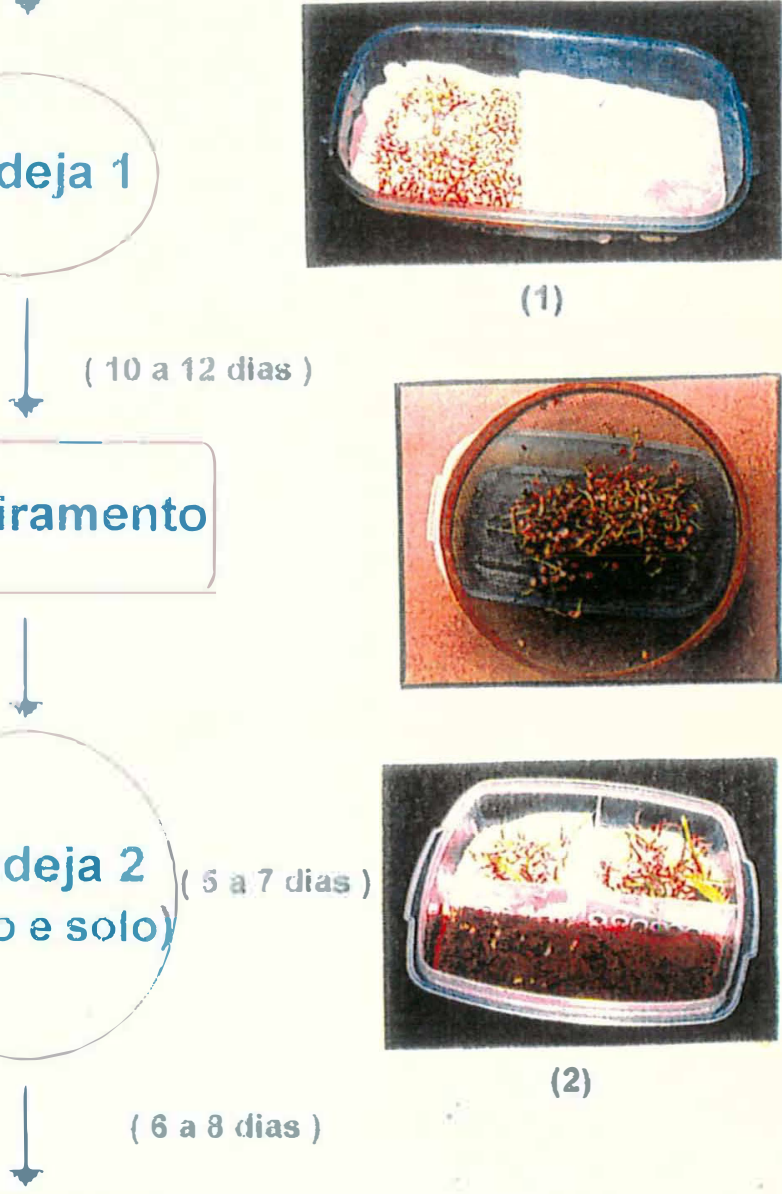

(1)
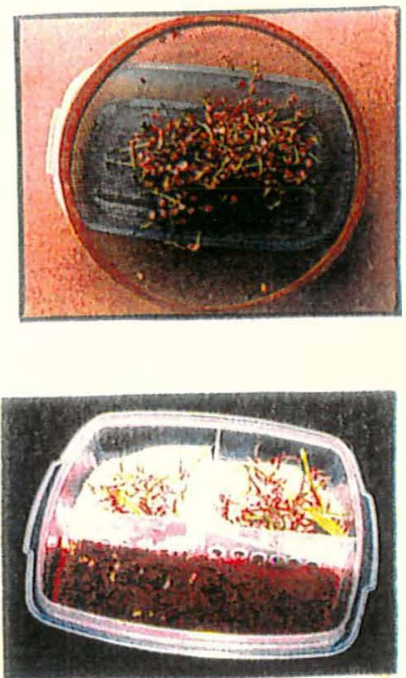

(2)

Figura 15. Sistema de criação de D. speciosa em dieta natural em condições de laboratório. 
4.7. Armazenamento de ovos de D. speciosa

Utilizando-se a temperatura base (Tb) para a fase de ovo, determinou-se que o período viável de armazenamento de ovos de $D$. speciosa, à temperatura de $11^{\circ} \mathrm{C}(\mathrm{Tb})$, foi de 56 dias com viabilidade de $64 \%$ (Tabela 16). O tempo de armazenamento de ovos de crisomelídeos varia em. função de apresentarem ou não diapausa. Assim, BRANSON (1978) armazenou ovos de $D$. virgifera por 52 semanas à $10^{\circ} \mathrm{C}$, sem perda de viabilidade. Segundo os autores LEW \& JACKSON ${ }^{6}$ e FISHER et al (1994), o tempo de armazenamento de ovos das espécies de crisomelídeos $D$. $u$. howardi e $D$. barberi, a temperaturas que variaram entre 9 e $12^{\circ} \mathrm{C}$, foi de 4 semanas a 180 dias, respectivamente. A possibilidade de armazenar ovos de D. speciosa favorece a manutenção de sua criação em laboratório, principalmente, na época em que a ocorrência de adultos é escassa no campo.

${ }^{6}$ LEW, A. C. \& JACKSON, J. J. Effect of temperatures on egg viability of southern corn rootworm (Coleoptera: Chrysomelidae) (Em elaboração). 
Tabela 16. Viabilidade de ovos de D.speciosa em função do tempo de armazenamento. Temperatura $11^{\circ} \mathrm{C} *$; UR 100\%; Escotofase $24 \mathrm{~h}$.

Tempo de armazenamento

(dias)

\section{Viabilidade}

(\%)

\begin{tabular}{cc}
\hline 0 & $78,0 \pm 12,1 \mathrm{a}$ \\
7 & $74,0 \pm 5,4 \mathrm{a}$ \\
14 & $80,0 \pm 2,6 \mathrm{a}$ \\
28 & $73,0 \pm 3,5 \mathrm{a}$ \\
56 & $64,0 \pm 2,3 \mathrm{a}$ \\
112 & $24,0 \pm 3,3 \mathrm{~b}$ \\
\hline Médias seguidas pela mesma letra não diferem entre si, pelo teste de \\
Tukey, ao nível de 5\% de probabilidade. \\
* Temperatura base da fase de ovo.
\end{tabular}




\section{CONCLUSÕES}

Os resultados obtidos com Diabrotica speciosa (Germar, 1824) permitem concluir:

1. O desenvolvimento embrionário independe da presença de luz no laboratório;

2. O período embrionário diminui com o aumento da temperatura, na faixa de 18 a $32^{\circ} \mathrm{C}$, não havendo porém efeito da temperatura na viabilidade deste período;

3. A dieta artificial, à base de germe de trigo e caseína, incluindo celulose, permite o desenvolvimento de $D$. speciosa;

4. A dieta artificial alonga o ciclo biológico (ovo-adulto) em relação à dieta natural;

5. O número de ínstares e a largura da cápsula cefálica são semelhantes para a larva criada em dieta natural e artificial;

6. As fêmeas de $D$. speciosa, criadas em dieta natural, durante a fase larval, são mais fecundas e menos longevas que as criadas em dieta artificial; 
7. A postura é realizada preferencialmente durante o dia, e as fêmeas colocam maior número de ovos no período das 14 às 18 horas;

8. Em dieta natural os picos de postura ocorreram no 30, 70 e 10 dias, enquanto que em dieta artificial o maior número de ovos foi colocado no 3 e 6o dias;

9. Há uma relação inversa entre a duração do período larvaadulto e aumento de temperatura, na faixa de 18 a $32^{\circ} \mathrm{C}$;

10. Os limites térmicos inferiores de desenvolvimento (temperatura base) da fase de ovo, do período larva-adulto e do ciclo biológico são 11,1; 10,9 e 11,0 $\mathrm{C}$, respectivamente;

11. As constantes térmicas da fase de ovo, período larva-adulto e do ciclo biológico são 119,1; 355,9 e 474,9 graus-dia, respectivamente;

12. As fêmeas têm preferência por ovipositar no solo Terra Roxa Estruturada Distrófica de coloração escura, com a umidade variando de 26 a $63 \%$;

13. Os substratos de oviposição (gaze) de coloração preta e verde são os preferidos para oviposição de D. speciosa;

14. As luzes BLB (ultra violeta), BL (ultra violeta) e B (azul) são as mais atrativas para os adultos de $D$. speciosa; 
15. O método usando plântulas de milho para o estudo do ciclo biológico de $D$. speciosa é adequado, e oferece condições para o desenvolvimento de um sistema de criação do inseto, em larga escala, em laboratório;

16. Ovos de D. speciosa podem ser armazenados na temperatura base $\left(11,1^{\circ} \mathrm{C}\right)$ por 56 dias. 


\section{REFERÊNCIAS BIBLIOGRÁFICAS}

ADKISSON, P. L.; VANDERZANT, E. S.; BULL, D. L.; ALLISON, W. E. A wheat germ medium for rearing the pink bollworm. Journal of Economic Entomology, Lanham, 53(5): 759-62, 1960.

ARESTEGUI, P. A. Plagas de la papa en Andahuaylas-Apurimac. Revista Peruana de Entomologia, Lima, 19(1): 97-8, 1977.

BALL, J. B. Spectral response of adult western corn rootworm (Coleoptera:Chrysomelidae) to selected wavelenghths. Journal of Economic Entomology, Lanham, 75 (5): 932-33, 1982.

BARTELD, R. J. \& CHIANG, H. C. Field studies involving the sex attractant pheromones of the western and northern corn rootworm beetles. Environmental Entomology, Lanham, 6(5): 853-61, 1977.

BERGER, R. S. Laboratory techniques for rearing Heliothis species on artificial medium. USDA. Agricultural Research Service. Presentation Paper, ARS. 4p., 1963.

BERTELS, A. Combate às pragas do milho, métodos de defesa.

Pelotas, Instituto Agronômico do Sul, 1956. 18p. (Boletim, 16). 
BERTELS, A. Combate às pragas do milho, no campo e armazém. Pelotas, Instituto Agronômico do Sul, 1974. 126p. (Boletim, 78).

BERTONI, M. S. La temperatura mínima secular de 1918. Anales Científicos Paraguayos, Série 2, Assunción, 5: 345-91, 1919.

BOETEL, M. A.; WALGENBACH, D. D.; HEIN G. L.; FULLER, B. W.; GRAY, M.E. Oviposition site selection of the northern corn rootworm (Coleoptera: Chrysomelidae) Journal of Economic Entomology, Lanham 85(1): 246-49, 1992.

BOTELHO, P. S. M.; SILVEIRA NETO, S. S.; SALleS, L. A. B.; BARBIN, D. BORGES, C. G. Teste de atração de Musca domestica L. com luzes de diferentes comprimentos de onda. 0 Solo, Piracicaba, 65 (2): 42-5, 1973.

BOWLING, C. C. Rearing of two lepidopterous pests of rice on common artificial diet. Annals of the Entomological Society of America, Lanham, 60(6):1215-6, 1967.

BRANSON, T. F. Optimum temperature for long-term storage of eggs of Diabrotica virgifera (Coleoptera: Chrysomelidae). Entomologia Experimentalis et Applicata, Dordrecht, 24(2): 199-200, 1978.

BRANSON, T. F. \& KRYSAN, J. L. Feeding and oviposition behavior and life cycle strategies of Diabrotica: evolutionary view with implications for manegement. Environmental Entomology, Lanham, $10(6)$ : 826-31, 1981. 
BRANSON, T. F.; ORTMAN, E. E. Host range of larvae of western corn rootworm. Journal of Economic Entomology, Lanham, 60 (1): 201-3, 1967.

BRANSON, T. F. \& ORTMAN, E. E. The host range of larvae of western corn rootworm: Further studies. Journal of Economic Entomology, Lanham, 63(3): 800-3, 1970.

BRANSON, T. F.; GUSS, P. L.; JACKSON, J. J. Mating frequency of western corn rootworm. Annals of the Entomological Society of America, Lanham, 70(4): 506-8, 1977.

BRANSON, T. F.; JACKSON, J. J.; SUTTER, G. R. Improved method for rearing Diabrotica virgifera virgifera (Coleoptera: Chrysomelidae) Journal of Economic Entornology, Lanham, 81(1): 410-414, 1988.

BRUST, G. E. \& HOUSE, G. J. Effects of soil moisture, texture, and rate of soil drying on egg and larval survival of sourthern corn rootworm (Coleoptera: Chrysomelidae). Environmental Entomology, Lanham, 19(3): 697-703, 1990a.

BRUST, G. E. \& HOUSE, G. J. Influence of soil texture, soil moisture, organic cover and weeds on oviposition preference of southern corn rootworm (Coleoptera: Chrysomelidae). Environmental Entomology, Lanham, 19(4): 966-71, $1990 b$. 
BUNTIN, D. G.; ALL, J. N.; MCCRAKEN, D. V.; HARGROVE, W. L. Cover crop and nitrogen fertility effects on southern corn rootworm (Coleoptera: Chrysomelidae)damage in corn. Journal of Economic Entomology, Lanham, 87(6): 1683-88, 1994.

CARVALHO, S. M. \& HOHMANN, C. L. Biologia e consumo foliar de Diabrotica speciosa (Germar, 1824) em feijoeiro (Phaseolus vulgaris L., 1753), em condições de laboratório.In: REUNIÃO DE PESQUISA DO FEIJÃO, 1, Goiânia, 1982. Goiânia, Resumos. CNPAF-EMBRAPA, 1982. 244P.

CHALFANT, R. B. \& MITCHELL, E. R. Some effects of food and substrate on oviposition of spotted cucumber beetle. Journal of Economic Entomology, Lanham, 60(4): 1010-12, 1967.

CHIANG, H. C. \& SISSON, V. Temperature relationship of the development of northern corn rootworm eggs. Journal of Economic Entomology, Lanham, $61(5):$ 1406-10, 1968.

CHRISTENSEN, J. R. Estudo sobre el gênero Diabrotica Chev. en Argentina. Revista de la Faculdad de Agronomia y Veterinaria, Tucuman, 10 (3): $516,1944$.

CINERESKI, J. E. \& CHIANG, H. C. The pattern of movements of adults of the northern corn rootworm inside and outside of corn fields. Journal of Economic Entomology, Lanham, 61(6): 1531-36, 1968. 
COSTA, J. M. Algumas pragas do fumo e seus meios de combate. Boletim Técnico Instituto Agronomico do Leste, Cruz das Almas, 1(2): 29$59,1954$.

CUTTEBERT JR, F. P. \& REID JR, W. J. Studies of sex attractant of banded cucumber beetle. Journal of Economic Entomology, Lanham, 57(2): 247-50, 1964.

DYAR, H. G. The number of molts of lepidopterous larvae. Psyche, Cambridge, 5: $420-2,1890$.

FISHER, J. R.; JACKSON, J. J.; LEW, A. C. Temperature and diapause development in the egg of Diabrotica barberi (Coleoptera: Chrysomelidae). Environmental Entornology, Lanham, 23(2): 166-71, 1994.

Gallo, D.; nakano, O.; Silveira Neto, S.; CARVAlHo, R. P. L.; BATISTA, G. C.; BERTI FILHO, E.; PARRA, J.R. P.; ZUCCHI, R. A; ALVES, S. B. Manual de entomologia, São Paulo, Agronômica Ceres, 1978. 531p.

GASSEN, D. N. Diabrotica speciosa, como praga do milho. Passo Fundo, EMATER; EMBRAPA- CNPT, 1986, 2p.

GEORGE, B. W. \& ORTMAN, E. E. Rearing the western corn rootworm in laboratory. Journal of Economic Entomology, Lanham, 55(2): 375-77, 1965. 
GONZALEZ, R.; CARDONA, C.; VAN SCHOONHOVEN, A. Biologiay morfologia de los crisomelideos Diabrotica balteata Le Conte y Cerotoma fascialis Erickson como plagas del frijol comun. Turrialba, San Jose, 32(3): 257-64, 1982.

HADDAD, M. L. \& PARRA, J. R. P. Métodos para estimar os limites térmicos e a fajxa ótima de desenvolvimento das diferentes fases do ciclo evolutivo de insetos. Piracicaba, FEALQ, 1984.12p.

HAJI, F. N. P. Biologia, dano e controle do adulto de Diabrotica speciosa (Germar, 1824) (Coleoptera: Chrysomelidae) na cultura da batatinha (Solanum tuberosum L.) 1981. 53p. (Doutorado-Escola Superior de Agricultura "Luiz de Queiroz" IUSP).

HENSLEY, S. D. \& HAMMOND, A. M. Laboratory techniques for rearing the sugarcane borer on an artificial diet. Journal of Economic Entomology, Lanham, 61(6):1742-43, 1968.

HILL, R. E. \& MAYO, Z. B. Distribution and abundance of corn rootworm species as influenced by topography and crop rotation in Eastern Nebraska. Environmental Entomology, Lanham, 9(1): 122-27, 1980. JACKSON, J. J. Diabrotica. In: SINGH, P. \& MOORE, R. F. ed. Handbook of Insect Rearing, Amstterdan, Elsevier Science, 1985. p. 237-54. 
JACKSON, J. J. Rearing and handling of Diabrotica virgifera and Diabrotica undecimpunctata howardi. In: KRYSAN, J. L. \& MILLER, T. A., ed, Methods for the study of pest Diabrotica. New York, Springer Verlag, 1986. cap. 2, p. 25-47

JACKSON, J. J. \& ELLIOTT, N. C. Temperature-dependent development of imatures stages of western corn rootworm, Diabrotica virgifera virgifera (Coleoptera: Chrysomelidae). Environmental Entomology, Lanham,17(2):166-71, 1988.

JAVIER, T. G. \& PERALTA, T. Evaluation cuantitativa del control biológico em três cultivos del Valle Mantanaro. Revista Peruana de Entormologia, Lima, 18(1): 69-71, 1976.

JOHNSON, T. B. \& TURPIN, F. T. Northern and western corn rootworm (Coleoptera: Chrysomelidae) oviposition in corn as influenced by foxtail populations and tillage systems. Jounal of Economic Entomology, Lanham, 78(1): 57-60, 1985.

KHALER, A. L.; OLNESS, A. E.; SUTTER, G. R.; DYBING, C. D.; DEVINE, O. J. R. Root damage by corn rootworm and nutrient content in maize. Agronomy Joumal, Madison, 77(5):769-74, 1985.

KIRK, V. M.; CALKINS, C. O.; POST, F. J. Oviposition preferences of western corn rootworm for various soil surface conditions. Journal of Economic Entomology, Lanham, 61: (5)1322-24, 1968. 
KRYSAN, J. L. Introducion, biology, distribution and identification of pest Diabrotica. In: KRYSAN, J. I. \& MILLER, T. A. , ed. Methods for study of pest Diabrotica. New York, Springer, Verlog, 1986. cap 1., p. 1-23. LADD JR., T. L.; STINNER, B. R.; KRUEGER, H. R. Influence of color and height of eugenol- baited stick traps on attractiveness to northern corn rootworm beetles (Coleoptera: Chrysomelidae). Journal of Economic Entomology, Lanham, 77 (3): 652-54, 1984.

LARA, F. M.; DE BORTOLI, S. M. \& OLIVEIRA, E. A. Atratividade de cores a alguns insetos associados ao Citrus sp. Anais da Sociedade Entomológica do Brasil, Jaboticabal, 5 (2): 157-63, 1976.

LEVINE, E. \& OLOUMI-SADEGHI, H. Management of diabroticite rootworms in corn. Annual Review of Entomology, Palo Alto, 36. 229- 55, 1991.

LEVINE, E.; OLOUMI-SADEGHI, H. \& ELLIS, C. R. Thermal requeriments, hatching patterns, and prolonged diapause in western corn rootworm (Coleoptera: Chrysomelidae eggs. Journal of Economic Entomology, Lanham, 85(6): 2425-32, 1992.

LEW, A. C. \& BALL, H. H. Effect of copulation time on spermatozoan transfer of Diabrotica virgifera (Coleoptera: Crysomelidae). Annual Entomology Society of America, Lanham, 73: 360-61, 1980. 
MARRONE, P. G. \& STINNER, R. E. Effects of soil moisture and texture on oviposition preference of the bean leaf beetle, Cerotoma trifurcata (Foster) (Coleoptera: Coccinelidae). Environmental Entomology, Lanham, 12( 2):426-28, 1983a.

MARRONE, P. G.; FERRI, F. D.; MOSLEY, T. R.; MEINKE, L. J. Improvements in laboratory rearing of the southern corn rootworm, Diabrotica undemcipucntata howardi (Coleoptera: Chrysomelidae), on artificial diet and corn. Journal of Economic Entomology, Lanham, 78(1):290-93, 1985.

MARRONE, P. G. \& STINNER, R. E. Effects of soil physical factors on egg survival of bean leaf beetle, Cerotoma trifurcata(Foster) (Coleoptera: Crysomelidae). Enviromental Entomology, Lanham, 12 (2): 673-78, $1983 b$.

METCALF, R. L. Foreword In: KRYSAN, J. L. \& MILLER, T. A. , ed. Methods for the study of pest Diabrotica New York, Springer Verlag, 1986. MILANEZ, J. M. Aspectos da criação de Diabrotica speciosa em condições de laboratório. In: Ata REUNIÃO SUL BRASILEIRA DE INSETOS DE SOLO, 1. Passo Fundo, CNPT-EMBRAPA, 1988. p. 29.

MIHSFELDT, L. H. Comparação de dietas artificiais para criação de Diatraea saccharalis (F., 1794). Piracicaba, 1985. 120 p. (MestradoEscola Superior de Agricultura "Luizde Queiroz"/ USP). 
PALMER, D. F.; WINDELS, M. B.; CHIANG, H. C. Artificial infestation of corn with western corn rootworm eggs in agar-water. Journal of Economic Entomology, Lanham, $70(3)$ : 277-78, 1977.

PANIZZI, A. R. \& PARRA, J.R. A ecologia nutricional e o manejo integrado de pragas. In: PANIZZI, A. R. \& PARRA, J. R. P., ed. Ecologia nutricional de insetos e suas implicações no manejo de pragas. São Paulo, Manole, 1991. cap. 9. p. 313 - 36.

PARRA, J. R.P. \& HADDAD, M. L. Determinação do número de ínstares de insetos. Piracicaba, FEALQ, 1989. 49p.

RAMALLO, J.C. \& WEEHT, S. Problemas sanitários del tabaco y sus medidas de control. Tucuman, Universidade Nacional de Tucumán/Faculdade de Agronomia y Zootecnia. Tucumán, 1976. (Boletin de Divulgacion, 5).

RICHARDS, L. A. Physical condition of waterin soil. In: BLACK, C. A., ed. Methods of soil analysis. Madison, Academic Press, 1965. cap. 8, p. $128-52$.

ROSE, R. I. \& McCABE, J.M. Laboratory rearing techniques for the southern corn rootworm. Journal of Economic Entomology, Lanham, $66(2): 398-400,1973$. 
SANTOS, B. Bioecologia de Phyllophaga cuyabana (Moser, 1918) (Coleoptera: Scarabaeidae), praga do sistema radicular da soja [Glycine max (L.) Merrill, 1917]. Piracicaba, 1992. 111p. (MestradoEscola Superior de Agricultura "Luiz de Queiroz" ESALQ-USP).

SCHAAFSMA, A. W.; WHITFIELD, G. H.; ELLIS, C. R. A temperaturedependent model of egg development of the western corn rootworm, Diabrotica virgifera virgifera Leconte (Coleoptera: Chrysomelidae). The Canadian Entomologist, Ottawa, 6(123): 1184 $97,1991$.

SCHALK, J. M. Rearing and handling of Diabrotica balteata. In: KRYSAN, J. L. \& MILLER, T. A., ed. Methods for the study of pest Diabrotica. New York, Springer Verlag, 1986. cap. 5, p. 49-56.

SGRILLO, R. B. A distribuição de Weibull como modelo de sobrevivência de insetos. Ecossistema, Espírito Santo do Pinhal, 7: 10-3, 1982.

SHAW, J. T.; PAULLUS, J. H.; LUCKMANN, W. H. Corn rootworm oviposition in soybeans. Journal of Economic Entomology, Lanham, 71 (2):189-91, 1978.

SHERWOOD, D. R. \& LEVINE, L. Copulation and its duration affects female weight, oviposition, hatching patterns, and ovarian developement in the wersten corn rootworm (Coleoptera: Chrysomelide). Journal of Economic Entomology, Lanham, 86 (6): 1664-71, 1993. 
SILVA, A. G. A,; GONÇALVES, C. R.; GALVÃO, D. M.; GONÇALVES, A. J. L.; GOMES, J.; SILVA, M. N.; SIMONI, L. Quarto catálogo dos insetos que vivem nas plantas do Brasil, seus parasitos $e$ predadores. Rio de Janeiro, Ministério da Agricultura, 1968. v.2, pt. 1, 622p.

SILVA - WERNECK, J. O.; DE FARIA, M. R.; ABREU NETO, B. P.; MAGALHÃES, B. P.; SCHMIDT, G. V. Técnica de criação de Diabrotica speciosa (Germ.) (Coleoptera: Chrysomelidae) para bioensaios com bacilos e fungos entomopatogênicos. Anais da Socieđade Entomológica do Brasil, Piracicaba, 24(1):45-52, 1995.

STEFFEY, K. L.; \& TOLLEFSON, J. J.; HINZ, P. N. Sampling plan for population estimation of northern and western corn rootworm adults in lowa cornfields. Environmental Entomology, Lanham, 11: 287- 291, 1982.

SUTTER, G. R. ; KRYSAN, J. L. \& GUSS, P. L. Rearing the southern corn rootworm on artificial diet. Journal of Economic Entomology, Lanham, 64(1): 65-67, 1971.

TURPIN, F. T.; DUMENIL, L. C.; PETERS, D.C. Edaphic and agronomic characteres that affect potential for rootworm damage to corn in lowa. Journal of Economic Entomology, Lanham, 65(6): 1615-19, 1972. 
WEISS, M. J.: MAYO, Z. B. \& NEWTON, J. P. Influence of irrigation pratices on the spatial distribution of corn rootworm (Coleoptera: Chrysomelidae) eggs in soil. Environmental Entomology, Lanham, 12 (4): 1293-95, 1983.

WILDE, G. E. Temperature effect on development of western corn rootworm. Journal of Kansas Entomology Socjety, Lawrence, 44. 185-7, 1971. 
ANEXOS 
Apêndice 1. Composição de dietas testadas para criação de $D$. speciosa (Germar, 1824).

Dieta A: BOWLING (1967)

\begin{tabular}{lc}
\hline \multicolumn{1}{c}{ Componente } & Quantidade \\
\hline Feijão & $100,0 \mathrm{~g}$ \\
Levedura & $15,0 \mathrm{~g}$ \\
Ácido ascórbico & $1,5 \mathrm{~g}$ \\
Metil-parahidróxibenzoato (nipagin) & $1,0 \mathrm{~g}$ \\
Ácido sórbico & $0,5 \mathrm{~g}$ \\
Formaldeído & $1,0 \mathrm{ml}$ \\
Ágar & $9,0 \mathrm{~g}$ \\
Água destilada & $625 \mathrm{ml}$ \\
\hline
\end{tabular}

Dieta B: MIHSFELDT (1985)

\begin{tabular}{lr}
\hline \multicolumn{1}{c}{ Componente } & Quantidade \\
\hline Farinha de milho & $197,8 \mathrm{~g}$ \\
Germe de trigo & $50,0 \mathrm{~g}$ \\
Levedura de cerveja & $53,0 \mathrm{~g}$ \\
Ácido ascórbico & $7,0 \mathrm{~g}$ \\
Ácido benzóico & $1,8 \mathrm{~g}$ \\
Metil-parahidroxi benzoato (nipagin) & $1,4 \mathrm{~g}$ \\
Ágar & $30,0 \mathrm{~g}$ \\
Água destilada & $1550,0 \mathrm{ml}$ \\
\hline
\end{tabular}


Dieta C: BERGER (1963)

\begin{tabular}{lr}
\hline \multicolumn{1}{c}{ Componente } & Quantidade \\
\hline Caseína & $52,5 \mathrm{~g}$ \\
Celulose & $7,5 \mathrm{~g}$ \\
Germe de trigo & $45,0 \mathrm{~g}$ \\
Ácido ascórbico & $6,0 \mathrm{~g}$ \\
Sacarose & $52,5 \mathrm{~g}$ \\
Sais de Wesson & $15,0 \mathrm{~g}$ \\
Aureomicina & $0,5 \mathrm{~g}$ \\
Cloreto de colina & $1,5 \mathrm{~g}$ \\
Metil-parahidoxibenzoato (nipagin) & $3,0 \mathrm{~g}$ \\
Ágar & $18,0 \mathrm{~g}$ \\
Mistura vitamínica & $15,0 \mathrm{ml}$ \\
Formaldeído & $0,75 \mathrm{ml}$ \\
KOH 4M & $7,5 \mathrm{ml}$ \\
Ácido acético glacial & $10 \mathrm{gotas}$ \\
Água destilada & $1260 \mathrm{ml}$ \\
\hline
\end{tabular}

Dieta D: HENSLEY \& HAMMOND (1968)

\begin{tabular}{lc}
\hline \multicolumn{1}{c}{ Componente } & Quantidade \\
\hline Caseína & $27,0 \mathrm{~g}$ \\
Sacarose & $45,0 \mathrm{~g}$ \\
Germe de Trigo & $27,0 \mathrm{~g}$ \\
Sais de Wesson & $9,0 \mathrm{~g}$ \\
Aureomicina & $250,0 \mathrm{ml}$ \\
Cloridrato de colina & $0,9 \mathrm{~g}$ \\
Ácido ascórbico & $3,6 \mathrm{~g}$ \\
Metil parahidroxibenzoato (nipagin) & $1,4 \mathrm{~g}$ \\
Formaldeído 37\% & $0,5 \mathrm{ml}$ \\
Solução vitamínica & $9,0 \mathrm{ml}$ \\
Ágar & $18,0 \mathrm{~g}$ \\
Água destilada & $780 \mathrm{ml}$ \\
\hline
\end{tabular}


Dieta E: SUTTER et al. (1971)

\begin{tabular}{|c|c|}
\hline Componente & Quantidade \\
\hline $\begin{array}{l}\text { Germe de trigo } \\
\text { Caseína } \\
\text { Sacarose } \\
\text { Celulose } \\
\text { Sais de Wesson } \\
\text { Metil-parahidroxibenzoato (nipagin) } \\
\text { Ácido sórbico } \\
\text { Colesterol } \\
\text { Óleo de linhaça } \\
\text { Estreptomicina } \\
\text { Aureomicina } \\
\text { Mistura vitamínica } \\
\text { KOH (10\%) } \\
\text { Formaldeido } \\
\text { Ágar } \\
\text { Água destilada }\end{array}$ & $\begin{array}{r}110 \mathrm{~g} \\
129 \mathrm{~g} \\
129 \mathrm{~g} \\
55 \mathrm{~g} \\
37 \mathrm{~g} \\
4 \mathrm{~g} \\
2,5 \mathrm{~g} \\
0,25 \mathrm{~g} \\
1,0 \mathrm{ml} \\
0,5 \mathrm{~g} \\
0,5 \mathrm{~g} \\
60,0 \mathrm{ml} \\
40,0 \mathrm{ml} \\
4,0 \mathrm{ml} \\
58,0 \mathrm{~g} \\
3360 \mathrm{ml}\end{array}$ \\
\hline
\end{tabular}


Apêndice 2. Análise química dos diferentes tipos de solo estudados

\begin{tabular}{llcccc}
\hline $\begin{array}{c}\text { Tipos de } \\
\text { Solo* }\end{array}$ & Localidade/Estado & $\mathbf{P}$ & $\mathrm{K}$ & $\mathbf{M . 0}$ & $\begin{array}{c}\text { pH } \\
\text { água }\end{array}$ \\
\hline & & & & & \\
(ppm) & $(\mathbf{p p m})$ & $(\%)$ & \\
T.R.E.D. & Faxinal dos Rosas, SC & 68 & 692 & 4,4 & 6,4 \\
T.R.E.L & ESALQ-USP,. SP & 16 & 110 & 4,0 & 4,3 \\
L.R. D. & Chapecó, SC & 17 & 162 & 2,6 & 5,7 \\
C.H.A. & Irani, SC & 7 & 122 & 4,7 & 4,7 \\
\hline
\end{tabular}

T.R.E. Terra Roxa Estruturada Distrófica

T.R.E.L. Terra Roxa Estruturada Latossólica

L. R. D. Latossolo Roxo Distrófico

C. H. A. Cambissolo Húmico Álico

Apêndice 3. Classificação de cores e análise granulométrica dos diferentes tipos de solo estudados

\begin{tabular}{llccccc}
\hline Tipos de & Cor & Código**$^{\star *}$ & $\begin{array}{c}\text { Areia } \\
\text { solo* }\end{array}$ & $\begin{array}{c}\text { Silte } \\
(\%)\end{array}$ & $\begin{array}{c}\text { Argila } \\
(\%)\end{array}$ & $\begin{array}{c}\text { Classe } \\
\text { (Textura) }\end{array}$
\end{tabular}

\begin{tabular}{|c|c|c|c|c|c|c|}
\hline T.R.E.D. & Vermelho & 2,5 YR (2/2) & 8 & 21 & 71 & muito argilosa \\
\hline $\begin{array}{l}\text { T.R.E.L. } \\
\text { L.R.D. }\end{array}$ & $\begin{array}{l}\text { vermelha } \\
\text { Vermelho } \\
\text { escuro }\end{array}$ & $\begin{array}{l}10 R(4 / 4) \\
2,5 Y R(3 / 6)\end{array}$ & $\begin{array}{c}29 \\
6\end{array}$ & $\begin{array}{l}18 \\
19\end{array}$ & $\begin{array}{l}53 \\
75\end{array}$ & $\begin{array}{l}\text { argilosa } \\
\text { muito argilosa }\end{array}$ \\
\hline C. H. A. & Bruno & 7,5 YR (5/4) & 13 & 21 & 66 & muito argilosa \\
\hline
\end{tabular}

* T.R.E.D. Terra Roxa Estruturada Distrófica

T.R.E.L. Terra Roxa Estruturada Latossólica

L.R. D. Latossolo Roxo Distrófico

C.H. A. Cambissolo Húmico Álico

** Codigo de cores : Segundo Munsell Soil Charts, 1988 